University of Louisville

ThinkIR: The University of Louisville's Institutional Repository

$5-2015$

\title{
The de-feminization of femininity : exploratory content analysis of gay male fashion magazines.
}

Christopher J. Vincent

University of Louisville

Follow this and additional works at: https://ir.library.louisville.edu/etd

Part of the Communication Commons, and the Feminist, Gender, and Sexuality Studies Commons

\section{Recommended Citation}

Vincent, Christopher J., "The de-feminization of femininity : exploratory content analysis of gay male fashion magazines." (2015). Electronic Theses and Dissertations. Paper 2134.

https://doi.org/10.18297/etd/2134

This Master's Thesis is brought to you for free and open access by ThinkIR: The University of Louisville's Institutional Repository. It has been accepted for inclusion in Electronic Theses and Dissertations by an authorized administrator of ThinkIR: The University of Louisville's Institutional Repository. This title appears here courtesy of the author, who has retained all other copyrights. For more information, please contact thinkir@louisville.edu. 
THE DE-FEMINIZATION OF FEMININITY:

EXPLORATORY CONTENT ANALYSIS OF GAY MALE FASHION MAGAZINES

\author{
By \\ Christopher J. Vincent \\ B.A., University of Louisville, 2013

\begin{abstract}
A Thesis
Submitted to the Faculty of the

College of Arts and Sciences of the University of Louisville

in Partial Fulfillment of the Requirements

for the Degree of
\end{abstract}

Master of Arts in Communication

Department of Communication

University of Louisville

Louisville, KY

May 2015 

THE DE-FEMINIZATION OF FEMININITY

\title{
EXPLORATORY CONTENT ANALYSIS OF GAY MALE FASHION MAGAZINES
}

\author{
By \\ Christopher J. Vincent \\ B.A., University of Louisville, 2013 \\ A Thesis Approved on
}

April 20, 2015

by the following Thesis Committee

Thesis Director, Dr. Steve Sohn

Dr. Kandi Walker

Dr. Kaila Story 


\section{DEDICATION}

This thesis is dedicated to my parents James and Denise Vincent, as well as my two older brothers Jeremy Vincent and Gemini Wink for their support in all of my educational endeavors and always encouraging me to follow my passions. In addition, I dedicate this to all my high school debaters and UofL Debate Family. Thank you for your words of encouragement and support. You are where I find my motivation to keep going.

Finally, this thesis is dedicated to all of the Queer/Quare/LGBT youth that I have had the opportunity to work with, coach, mentor, and provide life advice for. You are the reason for this thesis project, the ones that motivate me, and the reason why I'm still here. Always be true to who you are. 


\section{ACKNOWLEDGEMENTS}

I would like to thank my committee members for their guidance, patience, and commitment to my growth as a student and scholar. Specifically, I want to thank Dr. Steve Sohn for serving as my committee chair, and spending countless number of hours to help me fully develop this project, along with reading, editing, and being patient with me all the way to the end. Your comments, assistance, and patience caused me to grow and pushed me. I would also like to thank Dr. Kandi Walker and Dr. Kaila Story for agreeing to serve on my committee. The many conversations we have had and wisdom you have imparted is invaluable and I am forever appreciative.

Thanks is also given to the University of Louisville Debate Team both present and past, and Tiffany Dillard-Knox for giving me a platform to express my voice as an undergraduate, and then keeping me around to develop that voice into the coach and scholar I have become. In addition, Tiffany Dillard-Knox, you have helped me grow as a person, and helped me to find my voice. I will always be a part of "Debate What" and am grateful to call you a mentor, coach, boss, and friend.

Finally, a special thanks to my former debate partner and very close friend Aaron Weathers for constantly reminding me that I can get this done and always having a word of encouragement, and support, and for being there for me when I needed you the most. Thank you for being with me through this journey. 


\section{ABSTRACT \\ THE DE-FEMINIZATION OF FEMININITY \\ Christopher J. Vincent}

April 20, 2015

This thesis project is an exploratory content analysis that seeks to measure the ways in which gay male fashion magazine de-feminize their representations of feminine performing gay men. 125 images across five summer editions of Instinct Magazine, from 2010-2014, were randomly selected and were measured along the lines of race/ethnicity, fitness of clothing, build, touch, gaze, and body curvature. The research confirmed that gay male fashion magazines do in fact de-feminize their representations of femininity along these variables. The research also reflects pre-conceived ideas of representation along the boundaries of race. Using Michael Warners theory of Publics and Counterpublics as well as Judith Butler's theory of performativity, this project seeks to illustrate the danger of de-feminizing these representations, and seeks to challenge the way in which gay male fashion magazines articulate stereotypes surrounding feminine performing gay men. 


\section{TABLE OF CONTENTS}

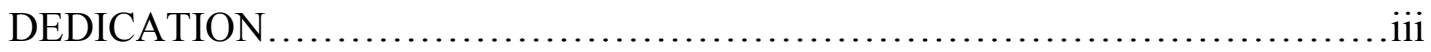

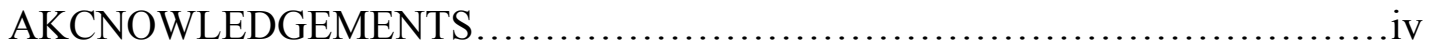

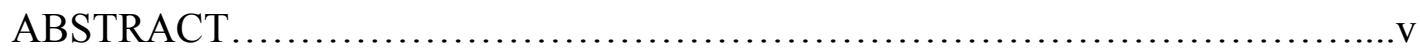

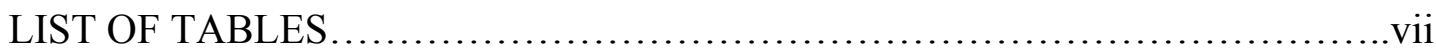
CHAPTER

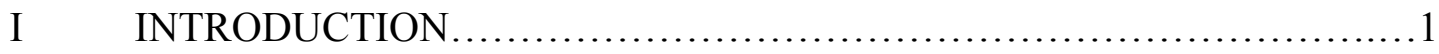

II REVIEW OF LITERATURE..........................................

Publics and Counterpublics.......................................6

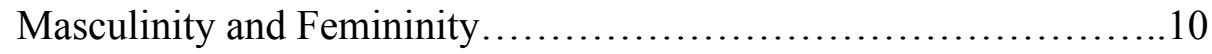

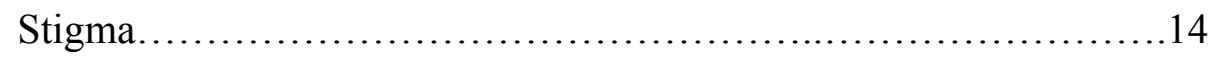

Representation in the Media.......................................18

A De-Feminized Race...........................................24

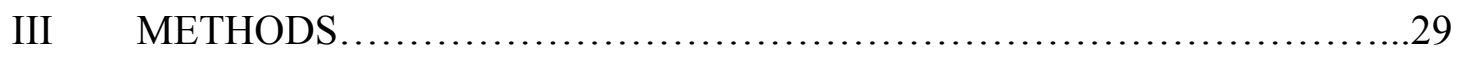

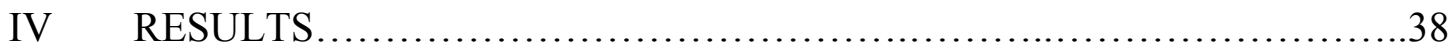

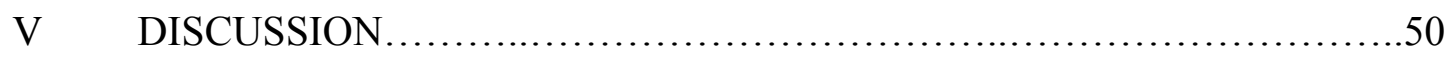

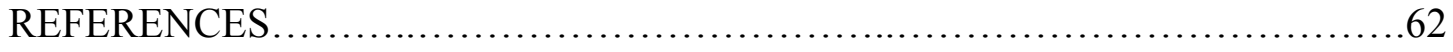

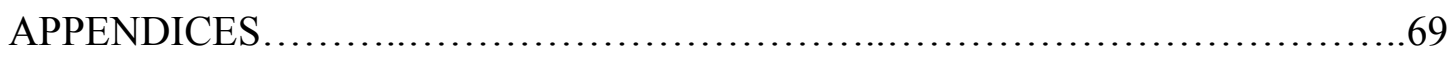

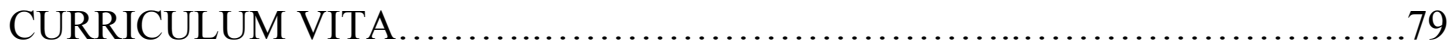




\section{LIST OF TABLES}

TABLE PAGE

1. Frequency of Degree of Clothing....................................

2. Frequency of Masculinity and Femininity.........................40

3. One-way Analysis of Variance of Fitness of Clothing...............41

4. Frequency of Build...........................................42

5. One-way Analysis of Variance of Build.........................43

6. Frequency of Touch...........................................44

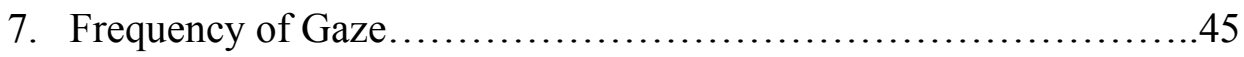

8. Frequency of Curvature.......................................... 46

9. One-way Analysis of Variance of Curvature.......................47

10. Race Distribution.............................................. 48

11. Chi-Square Results along race..................................49

12. Summary of Findings......................................... 76 


\section{CHAPTER I}

\section{INTRODUCTION}

Stereotypes are everywhere in our society, and have the powerful potential to

dictate and define who is the norm. A powerful controlling element of stereotypes is the ability of media outlets to regulate an image of those who are the norm. From the female models on the cover of Vogue magazine, to the trend setting men in $G Q$, to gay magazines like Instinct and Out, mainstream fashion magazines are responsible for the regulation of an image that determines who gets to be a part of the "in crowd." For those that do not fit into the mainstream construction, those bodies are pushed to the margin and forced to deal with the internalization of the message that mainstream ads create.

Femininity represents such a position. In its classical sense Butler (1993) isolates that "the classical association of femininity with materiality can be traced to a set of etymologies which link matter with mater and matrix (or the womb) and, hence, with a problematic of reproduction" (Butler, 1993, p. 31). From this classical tradition to a more complex understanding of the feminine as being out of "form/matter and universal/particular binarism" (Butler, 1993, p. 42), much of the work surrounding femininity has focused on the embodied female subject.

Along studies of sexuality, our understanding of sexual identity, orientation, gender and performance have become polarized. Sandfort (2005) argues that in 
traditional gay and lesbian work, the relationship between femininity and sexuality is often glossed over, as sexual orientation and gender are polarized in their study. Despite the glossing that appears to be happening, mainstream representation is beginning to break down these polarizing understanding of gender and sexuality. Mainstream shows like America's Next Top Model, Modern Family, Queer as Folk, and many others are grappling with the ways in which the male body can also embody a feminine performance. From Will Jardell wearing his six-inch heels and dealing with homophobic comments on America's Next Top Model, to the commercialization of RuPaul's Drag Race and the popular LOGO Television network, embodied and performative acts of femininity are beginning to pervade the public sphere. These constant representations require an understanding of how gay men negotiate the public sphere, and a thorough understanding of what these representations mean. "Dress communicates by breaking down the visual phase of social transactions into operations of seeing and appearing. Such communication relies on people visually interpreting and evaluating each other" (Cole, 2000).

As such, questions of male representation continue to shift and are renegotiated. Despite the glossing that happens in academia, it seems that men are beginning to respond more to consumer culture and are becoming more concerned about their appearance (Rohlinger, 2002). At the same time, there are particular subgroups that become rendered invisible and stigmatized as a result of the displaying of an unknown sexuality. Warner (1999) points out that the "dignified homosexual also feels ashamed of every queer who flaunts his sex and his bigotry, making the dignified homosexual's stigma all the more justifiable in the eyes of straights" (Warner, 1999, p. 32). It is here 
where the flamboyancy attached to feminine gay men becomes stereotyped and stigmatized.

Femininity is a unique site to explore, in relation to gay men for a couple of reasons. Sánchez \& Vilain (2012) point out that many gay men value traditional masculinity and marginalize feminine men. At the same time they found that many gay men learn how to de-feminize in order to protect themselves. De-feminizing means that while femininity is something that exists within the gay community, it is often something that is seen as taboo behavior. While heteronormativity attempts to regulate gay male identity, those who exist in the particular gay space seem to be buying into that regulation. Thus, men who embrace femininity often become the site of stigmatization and stereotype. Flamboyancy is something to work against, instead of something to embrace.

One of the ways in which this stigmatization and stereotype gets played out is through media images. That is why magazine images provide an important site to study the representation of the male body, as it becomes the ideal body that individuals strive to achieve (Rohlinger, 2002). The ideal body is one where it is difficult to determine sexuality, and it is also a portrayal that allows men to become sexual objects, focused on the sexualized displays of the body. Models, through the inherent focus on the sexualization of the male body, appear to have an unknown sexuality (Rohlinger, 2002). As Lanzieri \& Hildebrandt (2011) have suggested, “men are consistently seeing more images of physically fit and toned males in different advertisement genres. Even today's action toys are depicted as more muscular than they were 25 years ago" (p. 285). 
Depictions of muscularity in these genres suggest that advertising has a regulatory identity feature.

While work has been done in fields, such as gender studies, on performances of femininity, very little work has been compiled in the discipline of communication. Media representation is an important component to the discipline, yet little scholarship has focused on how gay men, in particular feminine gay men, are represented within the media. Yep, Lovaas, and Elia (2008) have challenged modern systems of sexuality, and have attempted to integrate that scholarship into the discipline of communication. Yep also explains that sexuality has largely been neglected in communication, arguing, "communication scholars are profoundly implicated in the maintenance of the homo/heterosexual binary" (Yep, 2003, p. 47).

It is necessary that communication begin to move beyond this binary and explore the intricacies of how identity is co-constructed between self and society. Yep goes on:

I urge communication teachers and scholars to interrogate and unpack the homo/heterosexual binary, disentangle and demystify the power of heteronormativity in our scholarship, pedagogy, and cultural politics, and to create and produce historically specific and embodied racialized knowledge of the human sexual subject (Yep, 2003, p. 48).

This research project is an attempt to produce that knowledge. In an effort to deconstruct this binary and expand the communication scholarship I will seek to examine the unknowingness of male sexuality in fashion ads. The goal of this thesis project is to explore what gay men are and are not responding to, by exploring the stigmatized and stereotyped location of feminine gay men. The unknowingness of sexuality in the ads represses an understanding of the bodies attached to the visibility of that sexuality that could reintrench its stigmatization. This project will seek to explore the stigmatized 
social location of the feminine performing gay man by examining how these bodies are represented within LGBT fashion magazines. I will engage in a critical content analysis of fashion ads from Instinct Magazine, a leading magazine targeting LGBT consumers, in an effort to deconstruct traditional conceptions of femininity and argue that current fashion portrayals attempt to de-feminize femininity, and in turn remove a unique site of empowerment for gay men.

This study does not attempt to define an image as necessarily being masculine or feminine, but instead explores the ways in each image can have masculine and feminine performing instances in the image. The analysis will demonstrate how gay male fashion magazines de-feminize their representations of femininity by counter-balancing them with masculine performing images. As such, each chapter helps to frame or expand this particular project. Chapter I has introduced this particular project and its importance for the discipline of communication. Chapter II explores two theoretical framings for this work, including Michael Warner's theory of Publics and Counterpublics, as well as Judith Butler's theory of performativity. In addition, previous literature on masculinity and femininity, stigmatization, media representation, and race are analyzed for their relationship to gay men and how it addresses this particular research project. Finally, the research questions are outlined. Chapter III explains the methodology used to answer the four research questions, as well as explains the process of selecting the images that were coded. Chapter IV presents the findings from the content analysis, while Chapter V discusses the meaning and significance of the findings. 
CHAPTER II

\section{REVIEW OF LITERATURE}

Publics and Counterpublics

As the backdrop of this work it is important to understand the ways in which stereotypes and stigmatization manifest within gay male culture. Michael Warner's work on queer theory provides the theoretical base to understand the way in which sexual identity is understood. Warner branches from Habermas' theory of the public and private sphere, to conceptualize what he terms as the public and the counterpublic. The counterpublic represents a queer space and a sexual culture for gay men and lesbians that are already set against a public sphere (Warner, 2010). Publics provide a space to understand how gender is "bound up with meaning of masculinity and femininity" (Warner, 2010, 24) and what these particular spheres say about the ways in which the body is represented. Warner's work is especially important when looking at the interaction of feminine gay men in fashion magazine, since it allows us to deconstruct socially ascribed meanings of gender.

The analysis of the public and private spheres are necessary because as Warner (2010) points out, that "any organized attempt to transform gender or sexuality is a public questioning of private life, and thus the critical study of gender and sexuality entails a problem of public and private in its own practice" (Warner, 2010, p. 31). Gay culture is 
inherently bound up with a question of the public and private sphere because the sexual life of a gay male is connected to normative understandings of sexual desire. The reason gay culture is bound up in both spheres is primarily because LGBTQ bodies must live in the straight world (Fee, 2000). As Fee points out " even if one attempts to live a "gay life" on an everyday basis, "moving from one gay institutional locale to the next," the experience of these locales is colored by the dominant heterosexist institutions and practices" (Fee, 2000, p. 46). Because there is never is never a set existence of gay life, the public and private spheres often blend together.

Thus, the theory of the public and the counterpublic provide a theoretical lens to position and challenge our static understandings of gender. Gender and sexuality, lived as a private life, is inevitably defined by its surrounding social structures and the public sphere:

Counterpublics are, by definition, formed by their conflict with the norms and contexts of their cultural environment, and this context of domination inevitably entails distortion. Mass publics and counterpublics, in other words, are both damaged forms of publicness, just as gender and sexuality are, in this culture, damaged forms of privacy (Warner, 2010, p. 63)

Queer life is bound up in the understandings of the public and private sphere since life is lived in both spaces. The private life is brought into the public sphere (Warner, 2010), and queer life in the counterpublic is defined in opposition to that same public sphere.

Publics and Counterpublics as a theoretical framing is necessary in order to understand the ways in which gay male fashion magazines target their audience. Instinct Magazine meets at the intersection of the public and the counterpublic because it attempts to articulate private notions of sexuality into the public sphere. An important component of the public and the counterpublic is that they, like performances of gender, are bound 
within a particular moment. Publics, according to Warner "commence with the moment of attention, must continually predicate renewed attention, and cease to exist when attention is no longer predicated" (Warner 2010, p. 88). That is why an understanding of the publics and counterpublics is absolutely crucial to an understanding of the marketing strategies of Instinct. Gay male fashion magazines represent the conflation of these two spheres and allow us to commence to the moment of attention. In other words, this theoretical framing allows an articulation of how gay male fashion magazines replicate normative understandings of sexuality and gender performance to ultimately influence the readership that appears in the counterpublics.

In addition, the theory of publics and counterpublics is uniquely tied to a disidentificatory act. How one reads the self within a particular moment is an important point of analysis. Understanding gay male fashion magazines as negotiating these two worlds allows for a thorough understanding of how their representations shape how particular bodies must interact in the sphere of the counterpublic. To be clear, the counterpublic is not just the LGBT population, but rather, it can be a particular performative moment that one lives in. A counterpublic is made up of various groups that perform various cultural identities. A counterpublic can come to exist in a nightclub, a particular street, or any other formation that allows bodies with similar commonalities to interact with one another. The counterpublic is constantly being renegotiated as the individuals and groups change. Thus, individuals can be a part of multiple counterpublics along various dimensions such as race, gender performances, drag culture, ballroom communities, and many more. This the formation of the queer counterpublic:

By queer culture we mean a world-making project, where world, like public, differs from community or group because it necessarily includes more people than 
can be identified, more spaces than can be mapped beyond a few reference points, modes of feeling that can be experienced as birthright. The queer world is a space of entrances, exits, unystematized lines of acquaintance, projected horizons, typifying examples, alternate routes, blockages, incommensurate geographies (Warner, 2010, p. 198)

Analyzing these magazines does not allow us to identify how a counterpublic is formed, but rather provides a framework for understanding how identity plays out for particular groups within the counterpublic. As a mainstream magazine targeted towards gay men, the image they construct constitutes the identity that is constructed as the norm. In addition, the counterpublic is seen as a place of performance. "Counterpublic performances let us imagine models of social relations" (Munoz, 1999, p. 33). This understanding allows us to connect how one constructs their gender performance in relation to particular media images. Thus, the media image shapes social relations that are formed within the counterpublic. As a result, femininity is measured as a counterpublic performance to re-imagine a new model. This theoretical framing moves us beyond recognition of the ways in which femininity is represented, to reinterpret these performances as sites of empowerment. For LGBT people of color, Munoz (1999) illustrates this act as a form of disidentification:

Disidentification is the third mode of dealing with dominant ideology, one that neither opts to assimilate within such a structure nor strictly opposes it; rather, disidentifcation is a strategy that works on and against dominant ideology. Instead of buckling under the pressures of dominant ideology (identification, assimilation) or attempting to break free of its inescapable sphere (counteridentification, utopianism), this "working on and against" is a strategy that tries to transform a cultural logic from within, always laboring to enact permanent structural change while at the same time valuing the importance of local or everyday struggles of resistance (p. 12)

Disidentification is a performative enactment of the counterpublic. In the context of analyzing magazine images, the theory of the counterpublic allows us to understand 
how particular populations, specifically feminine gay men, are able to carve out a space that works against dominant constructions of femininity. Further, this theoretical framing provides a lens to critique current representation. This work examines the importance of representation and space, while at the same time providing the justification to critically examine the representation that occurs in regards to feminine performing instances. This method of critique moves the analysis beyond an explanation of what, to exploring the significance of that representation.

Masculinity and Femininity

As an understanding of a subculture that exists in opposition to traditional conceptions of sexuality, it is important to illustrate the ways in which LGBT members challenge normative assumptions of what their identity means. One area where this is highly contested, and one that serves as a framing for this study, is gender performance. Particularly, gender enactments of masculinity and femininity for gay men are often highly contested. Judith Butler, in Gender Trouble (1999) provides a theoretical foundation to understand the meanings of masculinity and femininity. In order to understand what a feminine gay man means, it is important to trace the way in which this term changes across time, location, and spaces. Masculinity and femininity are articulated as performances attached to gender. Judith Butler seeks to understand the gendered body as performed, meaning "there is no ontological status apart from the various acts which constitutes its reality" (Butler, 1999, p. 173). This means that a performed gendered body is one that is understood in relations to social proscriptions of behavior. Gender as performed explains the reason why masculinity and femininity can 
never be static. These terms are fluid and socially constructed (Sanchez, Greenberg, Liu, \& Vilain, 2009), which means masculinity and femininity are only articulated and understood when it is attached to the body that enacts it. It is important to make the distinction that gender performance is not about the ability to choose gender, but rather:

Performativity is a matter of reiterating or repeating the norms by which one is constituted: it is not a radical fabrication of a gendered self. It is a compulsory repetition of prior and subjectivating norms, ones which cannot be thrown off at will, but which work, animate, and constrain the gendered subject, and which are also the resources from which resistance, subversion, displacement are to be forged (Butler, 1993, p. 22).

In other words, performativity is inherently tied to the social meaning that we already ascribe to gender. This is necessary in understanding that the constructs of masculinity and femininity are reflective of particular social patterns of behaving. As a result, defining masculinity and femininity is difficult since it changes across different circumstances. Mutchler (2000) points out that it is important to think about gender as something that is done in order to bridge the gap of gender as an institution and gender as practiced. Here, Mutchler (2000) moves the analysis of gender to not be theorized by its various roles and expectations, but rather to examine how individuals enact or challenge those gendered expectations. Gender is not something that can be examined divorced from the body, but instead the body becomes the starting point of the analysis. Using this analysis, gender is something that is done, and "doing gender is unavoidable because individuals are held accountable to "gendered" behavior appropriate to their sex" (Mutchler, 2000, p. 17). This plays back into Butlers understanding of performativity as the ability to be "reiterative power of discourse to produce the phenomena that it regulates and constrains" (Butler, 1993, p. 2). Here the body is able to enact gender performances that either enact or deviate from what the dominant culture has defined as 
normalized. This is important in the analysis of gay male sexuality, where gay male sexuality is often done in the context of expectations about masculinity (Mutchler, 2000, p. 17). This reinforces the idea that masculinity and femininity are bound up in social meanings of gender rather than biological distinctions of sex (Stets \& Burke, 2000). The authors do not to suggest that gender and sexuality should always be correlated, but rather extends theories of gender performativity to articulate a particular gay male subject position that is often removed from the center of research. Gender should not be conflated to sexuality, but gender performance should help us to articulate the representations of feminine gay men.

Sanchez, Greenberg, Liu, \& Vilain (2009) have conducted research that can help to understand this phenomena when they isolate that "the general perception is that gay men are not masculine" despite many gay men who value traditional masculinity. While some of the literature has defined masculinity as "tough, strong, and sexually adventurous with masculine ideals" (Sanchez, Greenberg, Liu, \& Vilain, 2009, p. 3), little literature exists as to what to associate to feminine gay men. This is primarily because femininity has no static definition, but is instead situated in particular contexts. In the context of gay men, femininity is defined as a form of hyperfemininity, which is to say that it is "a form of dramaturgical, glamourized femininity that bears little relation to those activities conventionally given over to women (Paechter, 2006).

Research has also attempted to explain masculinities and femininities as constructs whose meanings are influenced by a variety of factors: mass media, popular culture, legal considerations, local and wider masculinities and femininities, and community interactions (Paechter, 2006). Some studies have focused on challenging 
these understandings of femininity by attempting to recover the feminine by placing it at the center of their analysis of gender (Schippers, 2007). Understanding masculinity and femininity, as elements of gender performance, is uniquely important for gay men.

Some research has also attempted to define what features define masculinity. In body type, style, and dress, gay men counteract traits that would be considered feminine (Lanzieri \& Hilderbrandt, 2011). Emphasis on increasing the size of the upper chest, and muscles reinforces this (Lanzieri \& Hildebrandt, 2011). Male femininity is also symbolically constructed in the sense that being effeminate, a twink, or a bottom are seen as the embodiments of femininity (Schippers, 2007).

One study looked to measure how masculinity and femininity were defined for gay men and found that many defined these physical and personality traits as “stereotypically masculine (e.g., restrictive emotionality, competitive, and muscular body) and feminine (e.g., affective/emotional, passive, and small framed)” (Sánchez, Greenberg, Liu, \& Vilain, 2009, pp. 6-7). While affective/emotional and passive are personality traits, small framed is an important distinction to be made about physical representation as will be explored in more details in the methods section. Other research suggests that many gay men adopt ideologies of masculinity, associate it with physicality, strength, virility, and sexual prowess, and attempt to often associate with the masculine look (Halkitis, 2000, p. 132).

An important component of any discussion of masculinity and femininity is to also look at the ways in which people can embody both features at the same time (Sandford, 2005). Androgyny explains the ways individuals can possess both features and freely engage in their behaviors (Sandford, 2005). Despite the possession of both, 
femininity still appears to be less of a focus for much of the current research. That is why for the purpose of this research I do not look at the physical embodiment of androgyny, but instead shift my attention to only focus on the representation of feminine features. Other work has attempted to center femininity in their analysis. In his work on sissiography, Messias (2011) attempts to embrace "sissy" in order to flip the stigmatized social position of the feminine performing gay male. While the next section will explore stigmatization, this is important here because it is one of the only comprehensive research projects to move the analysis of the feminine to gay men.

\section{Stigma}

It is the constructions of femininity that have been stigmatized within both the public and the counterpublic, or the queer sexual space. The construction of the dramaturgical feminine performing individual reflects both a social stigmatization within the gay community and a stereotype by the straight community. Stigma and stereotypes, operating together, creates a dual conflict for those whose gender performances deviates from that which is acceptable. The flamboyant and feminine gay man can be found on mainstream television, and represented as someone constantly in need or helpless. These are found in shows like Glee's depiction of the flamboyant Kurt, Cam in Modern Family, and even gay television shows like The Prancing Elite. You can find description of them across YouTube videos, articles, and blogs as being "extra," uninteresting and even unappealing.

Michael Warner (1999) and Erving Goffman (1963) provide a foundation for understanding this phenomenon. Goffman's theory of “in-group purification” maintains 
that those within a particular group are able to maintain stigmatization because of "the efforts of stigmatized not only to 'normify' their own conduct but also clean up the conduct of others in the group" (p. 108) Goffman explores the way in which a stigmatized person may enact "identity ambivalence when he obtains a close sight of his own kind behaving in a stereotyped way, flamboyantly or pitifully acting out the negative attributes imputed to them" (Goffman, 1963, p. 107). Thus, in-group purification becomes a process that justifies stigmatizing the feminine performing acts. Warner (1999) proceeds to argue that those whose gender identity "differs from the norm are despised, often violently, whether they desire those of their own sex or not" (Warner, 1999, p.37). At the same time, gay men or lesbians that conform to gender norms can easily pass (p. 37).

Understanding in-group purification is necessary to explain what is deemed as acceptable behavior. Nardi (2000) explains this phenomenon when he contextualizes the rise of the modern gay movement:

Even in the years after the rise of the modern gay movement, the rhetoric about gender in many gay organizations and communities has often been oppositional in its tone and it questions the role of effeminate men, drag queens, and "fairies" in the political strategies and media images. Complaints about gay men acting like women ruining the struggle for equal rights for gays are heard among many conservative gay leaders (p. 5).

Goffman's theory of in-group purification is played out here, and provides a theoretical understanding of the historical context of this stigmatization. Feminine performing gay men are deemed as both unacceptable and a threat to the movement for equality. This suggests that equality in the gay community is either a false pretense, and that equality becomes code for passing or it could reinforce the argument made in the first chapter by Sanchez \& Vilain (2012) that gay men often value traditional notions of masculinity. 
Femininity poses a threat to both scenarios. This historical situation also explains the ways in which identity is both structured and perceived within the gay community. From the radical drag queen and fairy, to performative displays of femininity, rhetoric about the role of these behaviors remains oppositional. Masculine ideas become important to LGBT visibility, and as result of the over emphasis on those masculine ideas, the stigmatization of femininity tends to increase.

Additional research has explored the ways in which stigma is inherently tied to femininity. Men are often fearful of being labeled as effeminate and as a result are likely to have a defensive reaction and may also be negatively affected for violating sexuality and portraying the stereotype of effeminacy (Glick, Gangl, Gibb, Klumpner \& Weinberg, 2007). Gender, as defined, is performed and is often understood as a socially learned appearance (Jacob \& Cerny, 2004). The social stigma attached to femininity is easily understood here, because "mainstream male identities generally exclude feminine appearances, behaviors, and personality traits" (Jacob \& Cerny, 2004, p. 122). As a result, this research explains the ways in which social stigma is attached to those who depart from mainstream masculinity. While these authors focus on what is termed as "radical drag" in Baltimore, this study concluded that effeminacy created a form of "male identity dislocation" (Jacob \& Cerny, 2004). Being effeminate displaces the traditional ideas of maleness.

The exhibiting of feminine characteristics has the ability to make someone the target of both stigma and social sanction (Schippers, 2007). Schippers, in fact, goes into a lengthy analysis to explain why this stigma arises:

Men having and acting on erotic desire for each other disrupts the assumed naturalized, complementary desire between men and women, and weak, 
ineffectual, and compliant men dislodge physical strength and authority from the social position "man." And so we have the "fag," the "pussy", and the "wimp"kinds of men who enact hegemonic femininity (Schippers, 2007, p. 96).

Same-sex desire gets ruled as something that is contaminating and disrupting of the traditional understanding of masculinity (Schippers, 2007). This plays into the desire and necessity of the counterpublic that allows gay men to create their own space. Yet even in the counterpublic, acceptable behavior, dress, and gender performance becomes regulated. As Cole (2000) points out, dress "is a visible and conscious marker of this constructed or performed gender" (Cole, 2000, p. 8). Since gender is performed, the counterpublic regulates what it means to perform appropriate gender. The boundaries of sexuality are often blurred, creating an unknowingness of sexuality that becomes regulated into the mainstream media.

It would appear then, that eccentric features would be the basis of femininity, meaning that the unknowingness of sexuality is important. The stigmatization and stereotyping of femininity within the context of the counterpublic can easily be understood through the culture it is situated in. Gay culture has the ability to make one more aware of their body image. The more involved one is, the more likely they will be aware of their physical appearance and have lower self-esteem (Kousari-Rad \& McLaren, 2013). Gay men are often forced to negotiate masculinity and live up to both the fixed ideas of manhood and myths of gay identity. To identify within the public sphere, gym culture provides a way to frame how masculinity should be negotiated. The work of Alvarez (2008) focuses on this culture. His survey of 557 gay and bisexual men, in addition to interviews, took place from 1999-2005 and provides a comprehensive examination of what gay gym culture is about. Alvarez explores the way in which 
identity in gay gym culture is often discusses in relation to body types. When this is coupled with other documentaries on gay male body image obsession, it is easy to find that gay men often identify based on body types. The Adonis Factor, a DVD documentary, also sets a frame for understanding gay culture as a perpetuating look (Hines, 2010).

Additional research has confirmed that gay men often seek men "who possess muscular, lean, and athletic body types" (Lanzieri \& Hilderbrandt, 2011, p. 275). One reason could be that there is fear of being associated with femininity and being demasculinized (Lanzieri \& Hildebrandt, 2011). Stigma is further compounded for those who sit between being masculine and feminine. In fact, "there may be more gay men positioned between the masculinist and effeminist camps than there are at either extremes" (Taywaditep, 2008, p. 14). As a result, gender polarization tends to happen that reinforce stigmatization of femininity. The author cites a study of Murray in 1992 that found that many gay men are uncomfortable with drag queens and flaming queens who reinforce the stereotypes (Taywaditep, 2008). Gay men being uncomfortable with queens' plays into the ways in which femininity operates against the backdrop of masculinity and is often negatively portrayed.

\section{Representation in the Media}

Femininity operates against traditional creations of masculinity as the literature has previously pointed out. Against this backdrop, femininity is a socially ascribed process rather than a static existence. Thus, I use Butler's (1993) idea of performativity to express how to negotiate gender within advertising. It is not possible to point to 
characteristics that places meaning in the term femininity. Rather, this process is constituted by the moment it is enacted. Media can powerfully alter and shape our perceptions and relations to the world. Media as a site of analysis is important and as Kates (1999) points out, a queer reading allows us to explore the discursive nature of the ads and their impact in negotiating the meaning of sexuality. Mainstream media tends to over-emphasize the desire for a consumptive masculinity that tends to play out within gay male culture. An analysis of gay male television shows, such as Queer Eye and the resulting discussion boards of Straight Acting.com found that masculinity is often deconstructed and then re-idealized (Clarkson, 2005). The analysis found that while heteronormative masculinity is challenged, the result could "reposition White, urban, heterosexual masculinity as normative and dominant" (Clarkson, 2005, p. 202). As a result, even if it is positive representations, masculinity is centered on a consumptive logic and creates an identity that is shaped by the market (Clarkson, 2005).

Understandings of masculinity and femininity are becoming more connected to the ideas of consumption. Thus, acceptable identities become articulated into the mainstream media. Leavy, Gnong \& Ross (2009) found that femininity is often manifested through products and consumerism. While their research focused on exploring the mind-body dichotomy for women, this analysis is still important to the current research project because it illustrates that much of what we consume and the ways we performatively enact gender often become tied to the representations we see in mainstream media.

For the LGBT community, visibility is becoming even more prominent within mass media, and is "transformed through commercialization" (Tsai, 2010). This creates an understanding that representation is about inclusion. It is in the commercialization 
that stereotypes and perceptions of acceptable gender performances become articulated. It has a political meaning that serves as the "official sanction from Corporate America" (Tsai, 2010). While visibility has increased, little of that has changed depictions of femininity for gay men. Many companies have begun actively targeting GLBT consumers (Angelini \& Bradley, 2010). Other research has focused on the ways advertising will target ads towards LGBT audiences by marketing in gay magazines (Saucier \& Caron, 2008).

Other research suggests that an important piece of understanding the gay market is recognizing "minority consciousness" or the recognition of the exclusion based on their identity (Tsai, 2013). Media and "out-of the closet" advertisement feature characters that can easily be identified as gay (Tsai, 2013). Tsai (2013) found that "gay consumers' interactions with targeted advertising in popular media are impacted by their consciousness of being second-class and by hostile social context." It is from this understanding of advertising that one can also see that the implicit representation of gay men can easily be viewed in terms of homoerotic readings. Adverting creates images of people who are "just like everyone else" (Clarke, 2000, p. 7). Gay men are constructed through a homoerotic lens, where they are seen as objectified body parts. Through a homoerotic reading, the gay male becomes seen as hypersexual.

To understand feminine representation also requires an understanding of the way in which media can influence self-perception. Some scholars have explored the effects of imagery and symbols in relation to marketing tactics (Oakenfull \& Greenlee, 2005). Several have also attempted to explore the effects that gay advertising has on heterosexual and lesbian/gay communities through content analysis (Um, 2012). In 
addition, work has been completed to explore different focus groups that produced both gay and heterosexual readings of advertisements in magazine ads (Sender, 1999). Advertising also has the ability to reinforce our understandings of gender. "As an engine of consumption, advertising plays a strong role in promulgating dualistic gender roles and prescribing sexual identities" (Schroeder \& Zwick, 2004, p. 21). A queer reading of ads allows an exploration of the discursive nature of ads and how they negotiate meanings of sexuality (Kates, 1999). All of this research suggests that advertising plays a crucial role in both shaping, and regulating the ways in which we consume sexual identity.

While an earlier portion of this chapter explained the emphasis on masculinity that is often derived from a consumptive culture, it is important to understand the ways in which marketing is heavily influencing this look. Hegemonic masculinity is now seen as a "subversive bodily act" (Cole, 2000, p. 95). Fashion trends now become dictated by this masculine desire as they begin to adopt the "macho look" where they would wear clothes and "kept their hair short, beards \& moustaches clipped, and clothing fitted and matched" (Cole, 2000, p. 95). The adoption of the macho look creates a desire to co-exist between passing as straight and gay at the same time. The masculine self-presentation has emphasized "tight buttocks, 'washboard' stomachs, and pumped-up biceps and pectorals" (Cole, 2000, p. 119). Here, we are able to return to Judith Butler's theory of performativity to understand that gay men attempt to embody normative gender expressions of manliness. Advertising has reflected these desires, which is why many major apparel corporations understand the need to "re-evaluate the importance of gender depicted in gay and lesbian advertising content" (Oakenfull \& Greenlee, 2005, p. 423). 
This masculine self-presentation is inherently tied to how the magazines can be reflective of the counterpublic, the carved out queer space. For the purpose of this research, LGBT advertising/magazines are representative of the counterpublic given that they depict gay models, and appeal to gay consumers. Thus, the counterpublic creates a dual conflict that Michael Warner seeks to explain. He argues "the conflict extends not just to ideas of policy questions but to speech genres and modes of address that constitute the public or to the hierarchy among media" (Warner, 2010, p. 119). Media has the ability to influence and shape the bodies that define the counterpublic.

Since the current research project is focused on the counterpublic sphere represented in gay magazines, it is also important to investigate what research has been conducted on gay magazines. Two studies have been uniquely important to this. Saucier \& Caron (2008) conducted a content analysis of both content and media images in gay magazines. They posed the question as to how gay men are represented in advertisements and images in The Advocate, Genre, Instinct, and Out magazines and secondly what messages are being communicated in the articles. In the sections that focused on appearance they looked at men that compare themselves to youthful appearances. Another study compared magazine content in the UK and explored whether the magazines were appearance potent and found that in the UK, gay male magazines were more appearance potent than straight magazines (Jankowski, Fawkner, Sater, \& Tiggemann, 2014). Neither of these studies explicitly examines representations of femininity, or the lack of femininity in the magazines. This exposes a major need to expand this particular research. Rohlinger (2002) explores the construction of an unknown sexuality in mainstream advertising but also takes Goffman's analysis of 
gender advertisement to look at depictions of masculinity. Particularly, they explore the erotic male gaze and touch as a means to construct an unknown depiction of sexuality (Rohlinger, 2002).

As a final component of media representation, Schroeder \& Zwick (2004) offer a powerful and compelling understanding of how images and advertising shape our understandings of identity. They also provide a justification for attempting to interpret media images:

To interpret advertising images is to acknowledge their representational power both as cultural artifacts and as bearers of meaning, reflecting broad societal, cultural, and ideological codes. We need to keep in mind that photographsparticularly advertising photographs - are not mere pictures, accurately representing some external world: "the photograph both mirrors and creates a discourse with the world, and is never, despite its often passive way with things, a neutral representation" (Clarke 1997, 27-28). Our interpretations are meant to suggest possibilities, both in terms of what we take as intended messages as well as resistant meanings. Images, saturated by a long cultural history, constitute an engaging and deceptive culturally and historically bound visual language system. Advertising imagery — as a subset within this system — interacts with it, borrowing from and influencing the larger world of visual culture (Schroeder \& Zwick, 2004, p. 45).

Because advertising images are reflective of our cultural codes, this justifies the need for this analysis of representation to explore the significant meaning about the unknowingness of sexuality within the public sphere. The homoerotic construction of the male body blurs the line of masculinity and femininity, which makes the male body become an object of consumption. This renders the empowering site of femininity as nonexistent. Thus, the depictions must be analyzed through the lens of performativity. To negotiate gender as a site of performance allows an understanding of the spectrum of masculinity and femininity, in order to analyze not just what the objectified male body is, but also what it signifies. To understand this representation through the lens of 
performativity in the public sphere, creates meaning beyond the realm of features, and rather explores the lack of meaning given to the feminine body. For the gendered body to be performed requires an understanding of the body within the particular context it is represented in, and as already mentioned, how it is defined in relation to masculinity. A large portion of the research emphasizes reasons why femininity is stigmatized, and also explores how masculinity is represented. While questions of how masculinity are important, many of these analyses ignore the under representation of femininity. Despite the criticisms, feminine gay men do exist and as a result this stigma/stereotype requires careful consideration, which leads me to several research questions:

RQ1: Do current mainstream gay male fashion magazines depict masculinity and femininity?

RQ2: How often do masculine performing images appear over feminine performing images in Instinct Magazine?

RQ3: How does Instinct Magazine de-feminize femininity through its representation of the body?

\section{A De-Feminized Race}

One additional component of this analysis is also important. When gender is conceptualized as performed, various dimensions play a factor into the significance placed on that performance. Marlon Bailey's book Butch Queens Up In Pumps: Gender, Performance, and Ballroom Culture in Detroit argues that "performance is a critical means through which gender and sexual minorities survive in an oppressive world; it is also tantamount to creating a new one" (Bailey, 2013, p. 19). Gender performance is 
compounded when race is added to our analysis. Race provides an added level of complexity to this analysis because it is not merely sufficient to see how representations vary across race, but it also requires us to explore whether representation even exists across race. For example, some research points to the fact that "marketers consider gays to be 'relatively well-educated and affluent customers with much disposable income"” (Um, 2012, p. 135). As a result, portrayal of male and female homosexuals is often "distorted by their persistent projection of images of white, upper-middle-classsubjects"(Um, 2012, p. 137).

Doing a racial analysis is necessary as visibility continues to be an object of conversation across mainstream media. $L O G O$, the first gay cable network in the US, is overpopulated with white male representation (Avila-Saavedra, 2009). The article goes on to suggest that 'queer' is almost exclusively used to reference white gay males (AvilaSaavedra, 2009). This discourse analysis demonstrates the ways in which visibility is often attached to white representation. Due to the attachment to white representation it is necessary to do an analysis that looks at the ways in which race is accounted for in current gay mainstream fashion magazines and how femininity becomes non-existent across these dimensions. Avila-Saavedra (2009) encourages research to look at the intersections where media structures attempt to regulate the representations of real men. They argue that "additional attention is required to the way that mediated constructions not only trivialize gay masculinities but also heterosexual masculinities that fail to represent the values associated with 'real' men" (Avila-Saavedra, 2009, p. 19). Particularly, the author calls to look at the intersections of race, class, and gay identity. 
A racial analysis is necessary, especially when looking at advertising images, given that some companies have found themselves in the middle of controversies. For example, Abercrombie \& Fitch has come under close scrutiny for their racially exclusive depictions in their marketing and models (McBride, 2005). McBride (2005) has explored the ways in which the Abercrombie "Look Book" has used advertising schemes to dictate what kind of racialized and sexualized body can be depicted. In another essay of his book, Why I Hate Abercrombie \& Fitch, he argues that the marketplace of design allows us to understand how race, gender affect, body type, age, penis size, and style "construct and constitute what we come to accept, and in some cases to celebrate, as our value" (McBride, 2005, p. 88). This book is one of the more comprehensive and exhaustive research directed at racialized marketing tactics along the lines of sexuality.

Despite the lack of representation in mainstream media, research continues to suggest that discussions of masculinity and femininity are inherently bound up with questions of race and representation. Masculinity and femininity shifts based on cultural variations (Schippers, 2007). Previous research has demonstrated that there is a relationship between gender roles and racial prejudice (Ratcliff, Lassiter, Markman, \& Snyder, 2006). Eguchi (2011) examines the ways in which Asian gay men are always seen as feminine. Through an auto ethnographic study, Eguchi attempts to negotiate the feminine performative presentations of gay Asian American cultural identity constructions. For example, he cites research that shows how Western media portrays the curve of the body as a feminine emphasis. Han (2000) adds to this understanding of the way in which Asian gay men are depicted by exploring the difficulty of negotiating and integrating between both the Asian American and gay community. In addition to 
negotiating the aestheticized gay culture, Asian gay men struggle to be seen as masculine (Drummond, 2005) meaning that masculinity and femininity become inherently tied to race and ethnicity. As a result "Asian gay men appear to be both marginalized and stigmatized within the gay culture" and bodies, body image, and body identity become an important part of the Asian gay male identity (Drummond, 2005).

The same is often true for black gay men who feel they experience the same type of stigmatization. Writing from experience Delvon Johnson argues that:

It is rare that we see feminine black gay men on mainstream television, and or radio. If we do, usually it's in a spoof, or being made fun of. Even in LGBT media, we don't often find a lot of feminine black gay men being featured in magazines, or our own press. We want society to know that we can be just as masculine as the heterosexual male, so we do our best to portray what society says is acceptable in order to appear socially acceptable in public (Johnson, 2013).

The lack of visible representation necessitates understanding how this phenomenon is playing out across racial dimensions. In addition, cultural factors like machismo, religion, and family also dictate sexual scripts for Latino gay men (Mutchler 2000). As the author suggests:

Many gay Latino men in the United States are accountable to particular "raced" scripts for sex deriving from Latin cultures and to the U.S. models for sex. Studies document that Latino gay men believe they are under more extreme pressures from their families and ethnic cultural backgrounds to live out the heterosexual procreative scripts for sex-at least in the public eye (Mutchler 2000, p. 19)

Again, this plays into the way in which racial and cultural scripting dictates how individuals performatively enact gender. For those that do not have representation, E. Patrick Johnson provides a theory of performance that derives from Butler's notions of performativity, but repositions LGBT people of color as active agencies of change that has the ability to let group members turn, bend, or reflect back on social structures 
(Johnson, 2005). Termed as "Quare," Johnson allows us to understand the complexity of human sexuality and how it negotiates that sexuality across a racialized identity. Gender as performed here also allows individuals to perform their "self in a moment of selfreflexivity, that has the potential to transform one's view of self in relation to the world (Johnson, 2005, p. 138). Applying this theory to representation allows a thorough examination of the ways racialized gay men are positioned in mainstream media, and also in the counterpublic space of the gay magazine. A racialized analysis of gender performance, through this theory, helps to elucidate feminine representation. Previous research (as cited above) indicates that race plays a major factor in understanding constructs of masculinity and femininity. As a result, any analysis of these constructs must include race and must also understand how these distinctions play out in the gay male counterpublic.

This understanding of performance is necessary to expand the understanding of masculinity and femininity in advertising. When analyzing the gendered performance of the body, the analysis is able to move beyond the question of what is represented to the question of how it is represented, and what that representation signifies. Despite the significance of these representations, little scholarly research has addressed the intersections of race, femininity, and sexuality in mainstream advertising, which leads me to a fourth and final research question:

RQ4: How does de-feminization vary across race and ethnicity? 


\section{CHAPTER III}

\section{METHODS}

Magazine Selection

This content analysis used images from a selective distribution of five editions of Instinct Magazine. Particularly the summer editions from 2010, 2011, 2012, 2013, and 2014 are used. Instinct is a leading gay male fashion magazine and provides an adequate frame for understanding the ways in which gay male fashion trends and representation have changed over the past five years. Instinct Magazine made the list as a top choice for exploring gay male representation for several reasons. First, Instinct Magazine is heavily targeted to gay men. Secondly, their magazines depict "men of the month" to help answer research questions about acceptable gay lifestyle. In addition, Instinct ranks among the top 5 gay male magazines according to one site that referenced media audit. In honor of LGBT pride month in 2012, Instinct Magazine made the list of the top ten gay and lesbian magazines in the United States. Ranked at number three, their readership includes 128, 258 audience members (Cision, 2012). According to their media kit, Instinct argues that they are the number one gay men's lifestyle magazines:

Instinct serves anyone interested in the gay perspective on travel, fashion, entertainment, health/fitness, home, auto, technology and dating/relationships. Instinct's distinct voice and interaction with its readers has earned it a readership growth and loyalty that is unmatched by any other gay publication (Instinct). 


\section{Image Selection}

Images have been selected from the five editions of Instinct magazine. The research takes a combination of both advertisement and magazine generated images. Following similar methods conducted by Reichert \& Carpenter (2004), all images that took up half a page or more were included in the sample. In addition, the ads must "feature discernable adult models" (Reichert \& Carpenter, 2004). However, this analysis was extended to include images that depicted full body, head/face, upper torso/lower torso, or other parts of the male body. Images/advertisements that feature only text or images that are not bodily, as well as drawings and sketches, have been excluded from this analysis. Since most of the research has also isolated the ways in which male bodies have been eroticized and exploited in current fashion advertising, gay male models are the only ones included in this analysis. As an extension of feminine representation, there is also a small segment of "drag queens" that are also analyzed based on the ways in which drag queens have been targeted as having no place as well in the larger spectrum of visibility (Nardi, 2000).

This left the total number of available images at 240. Each image was then assigned an identification number, from 1-240. The July/August 2010 magazine had 36 images and were assigned the numbers 1-36, June/July 2011 had 57 images, and were assigned the ID numbers 37-93, June/July 2012 had 60 images, and were assigned ID numbers 94-153, June/July 2013 were assigned 154-195 with 42 images, and April/May 2014 were assigned the remaining numbers through 241 and had 45 images. It was important to trace the changes in masculinity and femininity over time, and so in order to ensure proportional representation of sample size over the past five years, 25 images were 
randomly selected from each edition of the magazine using the website RANDOM.org. Using the integer generator function, numbers were randomly assigned based on how many images were in the magazine. From there, the random numbers of 1 to 25 were chosen for each magazine. This left a sample size of 125 images, comprised of magazine content, advertisements, and the magazine covers, to be coded.

\section{Coding}

As much of the previous literature discussion explains, femininity exists within the realm of a performance, or in relation to masculinity. Thus, identifying explicitly feminine gay men is difficult. Since masculinity and femininity are performed, these images will be measured for instances where they are performed. Gay male attractiveness standards such as the ones isolated in research conducted by Pope, Phillips, \& Olivardia (2000), demonstrate that the idealized body is one who is athletic, muscular, and lean. This has been termed as The Adonis Complex (Pope, Phillips, \& Olivardia, 2000). In order to measure femininity, the coding scheme has been constructed to measure these gendered performances on a spectrum. I do not attempt to dictate whether an entire image is masculine or feminine, but rather to see if there are instances of femininity in the image. Each image featuring male bodily representation is coded and categorized based on appearance. The analysis is analyzed for demographic variables such as age range, and race/ethnicity. It is then coded for image type (whether it be magazine content or an advertisement), how many people appear in the image, what is displayed (face, upper/lower torso, full body) and will then be analyzed based on particular masculine and feminine performing features. In addition the images will be coded for levels of 
objectification. These measurements have been carefully developed based on five emerging themes from current research and previous studies of femininity: Style/Dress

As noted by Cole (2000), dress is a major physical marker of masculinity and femininity. As such this categorization is defined using two distinct measuring scales. Based on previous research by Cole (2000) the tightness of the clothing is important to measure, which makes the fitness of clothing the first scale.. These were measured on a three part scale ranging from loose fitting, fit, and tight fit. Loose fitting indicated more masculine and are clothes that hang loosely on the model, while tight fitting clothes represented a more feminine look.

Leavy, Gnong, and Ross' (2009) analysis also found that femininity is defined via products and consumerism. Thus, questions are asked about how often men appear in feminine products or outfits. These products include wearing visible makeup, heels, and other female outfits. It is also in style/dress where drag representation is coded. Each coder was asked to indicate the amount of male clothing, female clothing, and whether they appeared in drag.

Build

As most of the previous literature has suggested, appearance and build are important components of understanding masculinity and femininity. Lanzieri \& Hildebrandt (2011) point out that upper chest and muscularity are important traits of masculinity while being small framed are often signs of femininity. Measurements of build were conducted on a five-part scale ranging from muscular, athletic/fit, average, lean/fit, and skinny. Muscular was defined as a "bodybuilding type" and represented the 
highest level of masculinity. Athletic/fit was someone who was built and well toned, but not overly muscular. An average build was not thin or muscular, but appeared to have a normal body size. As the scale moves closer to feminine there is the lean/fit model who is thin, but somewhat toned, followed by the skinny model that is small, thin and has no muscular build whatsoever. Skinny, in this measurement, represented the highest level of femininity.

\section{Touch}

While Schippers (2007) isolates that touching of another man is seen as a feminine trait, since it disrupts hegemonic masculinity, this variable is more difficult since the range of men the analysis looks at are gay men. As such, Goffman's (1979) theory of the feminine touch is applied to this analysis. In Gender Advertisements he explains that:

Women, more than men, are pictured using their fingers and hands to trace the outlines of an object or to cradle it or to caress its surface (the latter sometimes under the guise of guiding it), or to effect a "just barely touching" of the kind that might be significant between two electrically charged bodies (Goffman, 1979, p. 29).

Along these lines Rohlinger (2000) explains that touch ranges from self-touch, touch with a female, male, both, or can be undetermined. These ranges have been slightly altered to account for the unique circumstance of gay male representation in gay magazines. As such several categories are measured. No touch at all indicated the model was not engaged in a touch. Touching an object represented a more masculine use of hands where the model was touching an object. An unknown touch was one that was indeterminate or one where the model was engaged in multiple touches. This sits in the middle of the spectrum and could be masculine or feminine. Touch with another and 
self-touch were coded as more feminine traits and were indicators that the model was touching or holding someone else, or was touching their own body.

Gaze

Gaze has been determined using the adopted version of Goffman's model for understanding the distinctions between male and female gazes. Rohlinger (2000) points out that male models often gaze at the audience, whereas female models focus their gaze in the distance. Thus, measuring femininity in gaze requires looking to see how eye contact is made in the images where it applies. Gaze includes mental drift (gazing in the distance), gazing at another model, self-gaze, an unknown gaze (indeterminate), gaze at the audience, or no gaze at all (images that did not have facial representation).

\section{Position}

Position is another emerging theme that derives from the current literature on understanding masculinity and femininity, and as such is also coded in this particular analysis. Schippers (2007) isolates that femininity is often equated to being a twink, a bottom, and passive. Eguchi (2011) explains that curve of the body is also a feminine trait. For that reason, how the model is positioned is also coded in two different stages. Since bottomhood is typically equated to femininity, the location of the model is important. Three locations are isolated in the data analysis: only model in the image, frontal location of the model, or the model could be located in the back. Secondly, position is measured in regards to bodily performance, specifically measuring the curvature of the body. Body curvature is measured between having no curve at all, slightly depicted as curved (slightly noticeable curve), curved (normal but noticeable curve), or very curved (body appears to bend heavily) in the images. No curve at all is 
more masculine and represents either standing, sitting, or laying straight. These are important distinctions for understanding the way the body is positioned as a means to understanding femininity. As such, the higher the curvature of the body meant the higher the level of femininity.

\section{Objectification/Sexualization}

Objectification and sexualization is the sixth, and final, category of coding, which speaks to the way in which gay men are often viewed as homoerotic or engaged in an unknown sexuality. Halktis (2000) explained that gay men do not just attempt to construct themselves as masculine but they are often seen as sexually prowess. As Bailey (2011) explained, penis size and gender affect are important distinctions for understanding acceptable forms of sexuality. Thus, how gay men are both sexualized and objectified is an important measurement in this analysis. To measure levels of objectification required measuring how much clothing a model has on. This ranges from fully clothed, partially clothed, barely clothed, and not clothed at all. In addition, images were coded to see if they were displayed with a sexual object, sexual text, or if there was emphasis on male sex (including emphasis on penis size, or clothing types), through simple yes or no questions.

Each variable listed above provides a sufficient understanding of the ways in which masculinity and femininity are depicted. Style/Dress, build, touch, gaze, position, and objectification/sexualization help to expand current theories of sexuality and thoroughly allow an understanding of whether gay male fashion magazines depict masculinity and femininity (RQ1), how often one type of image appears over the other 
(RQ2), and how representations of the body influence the process of de-feminization (RQ3). In addition, the demographic data received in the coding process helps to also measure this phenomenon across the boundaries of race and ethnicity.

\section{Intercoder Reliability}

In order to conduct this research, two coders were used. Two coders were asked to look at a sample distribution of images from the summer editions of Instinct Magazine from 2010 to 2014. A codebook (APPENDIX A) as well as a coding answer sheet (APPENDIX B) has been carefully constructed in order to address the research questions that are isolated in chapter II and to provide a clear and consistent definition of variables that are being measured. Each coder was carefully trained using 3 images from each edition of the magazine (that will not be analyzed in the actual data set), and a Cohen's Kappa was calculated, $\mathrm{K}=.90$. After coders were considered sufficiently reliable they were then provided the sample to be coded. Each coding form consisted of basic demographic data including age range, race, and also image details such as the type of image, number of people in the image, and what part of the body was represented. If the display included different parts of the body, they were assigned the same image ID. When two or more people appeared in an image, each person was assigned a separate image ID. For instances when there was a coding conflict between the two coders, a third coder was brought (Coder C) in and their coding overruled coders A \& B. 
After all of the data has been coded, several tests have been run to measure each of the research questions. To measure RQ1 and RQ2 simple frequency tests were run to measure the raw percentages of how often femininity and masculinity were depicted in Instinct Magazine. To measure RQ3 a combination of frequency tests and one-way ANOVA's were run. In particular, a one-way ANOVA was run to measure build, curvature, and clothing fit, since these were constructed as ordinal scales. This measures de-feminization between the image and the isolated criteria of masculinity and femininity (as mentioned above). To measure RQ4 around race and ethnicity, a frequency of distribution across race was run, followed by a chi-square analysis to measure variance across racial groups. 


\section{CHAPTER IV}

\section{RESULTS}

In this study, 125 images from 5 editions of instinct magazine were analyzed to measure how often performative instances of masculinity and femininity appear in Instinct magazine and to examine the ways in which current gay male fashion magazines attempt to de-emphasize representations of femininity. The coded data was placed into SPSS to be analyzed.

Before analyzing the research questions, the data was analyzed for basic demographic purposes (Appendix C). The age group of young adult from the age range of 19-35 occurred more frequently. This meant 89 of the 125 models analyzed were categorized as young adult, while only two (1.6\%) were ages 18 and below, and 34 $(27.2 \%)$ were ages 36 and above. Of the images that were categorized, $76(60.8 \%)$ were advertisements, while only $49(39.2 \%)$ were actually magazine content. In addition, the number of people that were in the image was also analyzed. Of those 125 images, 42 (33.6\%) featured one person, $51(40.8 \%)$ featured two people, five (4\%) featured three people, thirteen $(10.4 \%)$ featured four people, and thirteen $(10.4 \%)$ featured five or more people. The additional component that is important to this analysis is what type of bodily representation is featured. A large portion of the images contained upper torso images $(59.2 \%)$ while $35.2 \%$ were full body depictions and $5.6 \%$ were only face images. It is 
important to note that these are the only three image types that appear in this sample.

Table one also indicates the amount of clothing appearing on the bodies. Of the sample size 73 images (58.4\%) were fully clothed, 17 were partially clothed (13.6\%), 17 were barely clothed (13.6\%) and 18 were not clothed at all (14.4\%). This particular variable helps to measure representations of masculinity and femininity in relation to how the gay male body is objectified. Of the 18 that were not cloth at all, it did not depict full frontal nudity. Rather, it was a noticeable removal of the clothing. Their body was often covered by some kind of text, or some sort of object. The 17 that were partially clothed, had at least half of their body covered (more than 1 item), whereas the 17 that were barely clothed may have had only one item of clothing on.

\section{Table 1}

Frequency of Degree of Clothing

\begin{tabular}{lll}
\hline & Frequency & Percent \\
\hline Fully Clothed & 73 & $58.4 \%$ \\
Partially Clothed & 17 & $13.6 \%$ \\
Barely Clothed & 17 & $13.6 \%$ \\
Not Clothed & 18 & $14.4 \%$ \\
Total & 125 & $100.0 \%$ \\
\hline
\end{tabular}

Research questions one and two simply measured whether or not masculinity and femininity was depicted in the magazines and if so, how often masculine-performing images appeared over feminine performing images. In order to measure this, frequency tests were run. Of the categories and 125 images that were evaluated for masculinity and femininity, there were 625 possible depictions along the bases of clothing fit, build, 
touch, gaze, and body curvature. Adding masculine and feminine images resulted in there being 336 depictions of masculinity, 211 images of femininity, and 78 that were indeterminate. This particular frequency answers research questions one and two to indicate that gay male fashion magazines do depict masculine and feminine performing images, and that masculine images appear more frequently over feminine performing images, as indicated in table 2 .

\section{Table 2}

Frequency of Masculinity and Femininity

\begin{tabular}{lll}
\hline & Frequency & Percent \\
\hline Masculine & 336 & $53.8 \%$ \\
Performing Instances & & \\
Feminine Performing & 211 & $33.8 \%$ \\
Instances & 78 & $12.4 \%$ \\
Indeterminate & 625 & $100.0 \%$ \\
Total & & \\
\hline
\end{tabular}

The Process of De-Feminization

Research question three attempted to measure how Instinct magazine defemininizes femininity through its representation of the body. Five variables helped to measure masculinity and femininity. Those included style/dress, build, touch, gaze, and body position. To measure de-feminization for each of these variables, frequency tests were run for each category. For data that was analyzed on a scale, a one-way ANOVA was also run comparing the degree of clothing and the categories of masculinity and 
femininity. Degree of clothing was chosen because it provided the most significant category to measure between the representation of the body and the levels of femininity.

\section{Style/Dress}

Of the 125 images, 5 of the models were wearing loose fitting clothes, 65 were wearing fit clothes, and only 35 were wearing tight fit clothing. Of the images, only 10 were depicted wearing female clothing, and only one appeared to be in drag. Of the 125 images, only $21(16.8 \%)$ were either not depicted in male clothing or were not wearing clothing at all. In addition, ten images were depicted wearing some form of female clothing, and only one appeared to be wearing drag. Additionally, a one-way ANOVA was conducted to measuring significance of the fitness of clothing in relation to the degree of clothing that was being worn. There was a significant effect on the degree of clothing to fitness illustrating that de-feminization does happen across fitness: $F(3$, 121) $=103.53, p<.001$ (Table 3$)$.

\section{Table 3}

One-way Analysis of Variance of Fitness of Clothing

\begin{tabular}{lrrrrr}
\hline \multicolumn{1}{c}{ Source } & df & \multicolumn{1}{c}{ SS } & MS & F & \multicolumn{1}{c}{ p } \\
\hline Between groups & 3 & 85.78 & 28.59 & 103.53 & .000 \\
Within groups & 121 & 33.42 & .28 & & \\
Total & 124 & 119.20 & & & \\
\hline
\end{tabular}

A LSD post-hoc analysis was conducted on all possible pairs and found significant difference between the fitness of clothing and the degree of clothing being worn $(\mathrm{p}<.01)$. In measuring clothing fit, fully clothed $(\mathrm{M}=2.12, S D=.50)$ was found to be significantly different then barely clothed $(\mathrm{M}=2.88, S D=.33)$ and no clothing $(\mathrm{M}=$ 
$.00, S D=.00$ ). While partially clothed did not show a significant difference between fully clothed, it did show a difference between partially clothed $(\mathrm{M}=2.12, S D=.93)$ and barely clothed, as well as not clothed. Barely clothed and not clothed also showed a significant difference. When it came to the tightness of clothing, the more layers of clothing a model had on indicated the more loose fitting their clothing was and as a result appeared more masculine, while the less clothing a model had on resulted in more tight fit clothing and as a result was more feminine. In addition, when it came to fitness of clothing there were more masculine depictions than there were feminine depictions. Fit and loose fitting were considered more masculine to follow in line with Cole (2000) work on gay male dress.

\section{Build}

Build represented a second dimension of measuring masculinity and femininity. To determine how de-feminization occurs, a frequency test was run. Muscular, athletic/fit, and average were determined to be representative of masculinity, while lean/fit, and skinny were determined to be representative of femininity. While earlier studies have confirmed that muscularity and masculinity are often over-emphasized in gay male culture, table 4 shows that this study found that only four of the 125 images were depicted as muscular. As shown in table 4, a total of 72 images $(58 \%)$ were coded as being more masculine in representing how one is built.

\section{Table 4}

Frequency of Build

\begin{tabular}{lcc}
\hline & Frequency & Percent \\
\hline Muscular & 4 & $3.2 \%$
\end{tabular}




\begin{tabular}{lll}
\hline Athletic/Fit & 34 & $27.2 \%$ \\
Average & 34 & $27.2 \%$ \\
Lean/Fit & 35 & $28.0 \%$ \\
Skinny & 18 & $14.4 \%$ \\
Total & 125 & $100.0 \%$ \\
\hline
\end{tabular}

Since build was also coded on a scale from muscular to skinny, another one-way ANOVA was conducted. This demonstrated there was a significant difference in representation along build $F(3,121)=5.5, p<.01$ (Table 5). A LSD post-hoc analysis was conducted on possible pairs and found difference between degree of clothing/body representation and only found significant difference between being fully clothed ( $\mathrm{M}=$ $3.55, S D=1.04)$ and partially clothed $(\mathrm{M}=2.94, S D=1.14)$, barely clothed $(\mathrm{M}=2.71$, $S D=1.10)$, and being not clothed $(\mathrm{M}=2.72, S D=.89)$. There was no significant difference found anywhere else. This proved that while there was an association between more clothes and the build of the model, there was not a significant difference between less clothes and build of the model. This means there is not a relationship between the degree of clothing and build with any statistical significance. While there was not a difference between degree of clothing and build, there were fewer feminine performing images than masculine ones.

\section{Table 5}

One-way Analysis of Variance of Build

\begin{tabular}{lrrrrr}
\hline \multicolumn{1}{c}{ Source } & df & \multicolumn{1}{c}{ SS } & MS & F & p \\
\hline Between groups & 3 & 18.11 & 6.04 & 5.53 & .001 \\
Within groups & 121 & 132.16 & 1.09 & & \\
Total & 124 & 150.272 & & & \\
\hline
\end{tabular}




\section{Touch}

Touch, the third dimension of masculinity and femininity was measured only categorically. As a result only a frequency test was run to determine how often more feminine performing images were depicted. Table 6 shows that 30 images $(24 \%)$ were not depicted in a touch at all, while $28(22.4 \%)$ were touching an object, $14(11.2 \%)$ were engaged in an unknown touch, $32(25.6 \%)$ were engaged in a touch with another, and 21 $(16.8 \%)$ were engaged in some form of self-touch. According to previous research conducted by Goffman (1979), touch with another and self-touch reflected more feminine traits, it appears there was not a significant de-feminization across the lines of touch. Table 6 indicates that there is a fairly even distribution of touch along masculine and feminine performing instances.

\section{Table 6}

Frequency of Touch

\begin{tabular}{lll}
\hline & Frequency & Percent \\
\hline No Touch At All & 30 & $24.0 \%$ \\
Touching An Object & 28 & $22.4 \%$ \\
Unknown Touch & 14 & $11.2 \%$ \\
Touch With Another & 32 & $25.6 \%$ \\
Self-Touch & 21 & $16.8 \%$ \\
\hline Total & 125 & $100.0 \%$ \\
\hline
\end{tabular}

Gaze

Gaze was also measured categorically, only running a frequency analysis. While 4 of the images (3.2\%) were engaged in no form of gaze, 64 of the 125 images were 
gazing at the audience (51.2\%). Fourteen were engaged in an unknown gaze (11.2\%), while only three $(2.4 \%)$ were engaged in a self-gaze. Along the lines of a more feminine gaze, only $31.6 \%$ were either engaged in a gaze at another model or mental drift. In line with Rohlinger (2000) study male models gaze at the audience and female model focus their gaze in the distance. The frequency chart shows that Instinct depicts more masculine performing instances of gaze than it does feminine performing instances, showing that de-feminization does happen when it comes to the models gaze.

\section{Table 7}

Frequency of Gaze

\begin{tabular}{lll}
\hline & Frequency & Percent \\
\hline No Gaze & 4 & $3.2 \%$ \\
Gaze at Audience & 64 & $51.2 \%$ \\
Unknown type of gaze & 14 & $11.2 \%$ \\
Self-Gaze & 3 & $2.4 \%$ \\
Gaze at Another Model & 27 & $21.6 \%$ \\
Mental Drift & 13 & $10.4 \%$ \\
\hline Total & 125 & $100.0 \%$ \\
\hline
\end{tabular}

\section{Body Position}

Body position was measured on two levels. First, where the model was positioned was measured through a frequency test. Of 125 images, 65 models were pushed to the front of the image, while 17 were located behind someone else, and 43 were not pictured with anyone. 
Body curvature is also an important component to measuring how a masculine or feminine performing image appears. To measure curvature of the body a frequency test indicated how often a model was depicted with a curved body. Table 8 shows this frequency. No curve at all (24.8\%), and slightly curved (45.6\%), were reflective of more masculine instances, while curved (16\%) and very curved (5.6\%) were more feminine instances. In line with previous research, slightly curved, and no curve at all represented more masculine performing, and as a result more masculine performing instances were represented along body curvature, over feminine performing instances.

\section{Table 8}

Frequency of Curvature

\begin{tabular}{lrr}
\hline & Frequency & \multicolumn{2}{c}{ Percent } \\
\hline Not Pictured & 10 & $8.0 \%$ \\
No Curve at All & 31 & $24.8 \%$ \\
Slightly Curved & 57 & $45.6 \%$ \\
Curved & 20 & $16.0 \%$ \\
Very Curved & 7 & $5.6 \%$ \\
\hline Total & 125 & 100.0 \\
\hline
\end{tabular}

Since body curvature was measured on a scale, a one-way ANOVA was conducted to measure significance between the amount of clothing/body representation and the curvature of the body. A significant difference was found $F(3,121)=4.22, p<.01$ (Table 9). A LSD post-hoc analysis was conducted to determine where significant difference occurred in regards to body curvature. A significant difference was found between fully clothed $(\mathrm{M}=1.71, S D=.86)$ and barely clothed $(\mathrm{M}=2.59, S D=.87)$. A difference was 
also found between barely clothed and partially clothed $(\mathrm{M}=1.94, S D=.90)$, as well as not clothed $(\mathrm{M}=1.72, S D=1.27)$. No other significant difference was found. This meant that the more layers of clothing a model had on, did not affect the amount of curvature the model appeared to have.

\section{Table 9}

One-way Analysis of Variance of Curvature

\begin{tabular}{lrrrrr}
\hline \multicolumn{1}{c}{ Source } & df & \multicolumn{1}{c}{ SS } & MS & F & \multicolumn{1}{c}{ p } \\
\hline Between groups & 3 & 11.06 & 3.69 & 4.22 & .007 \\
Within groups & 121 & 105.63 & .87 & & \\
Total & 124 & 116.69 & & & \\
\hline
\end{tabular}

\section{Objectification/Sexualization}

A final categorization under this research question was also to confirm previous studies about the ways in which objectification happens in gay male fashion magazine. In addition to levels of clothing, which have already been discussed above (table 1), three questions were asked to determine how often sex was emphasized in each of the images. The first question asked whether the models were displayed with some form of a sexual object and only 13 images did appear to be displayed with such objects. 14 of the images were displayed with sexual texts, and 28 of those images had emphasis on male sex. Along the lines of other objects, text, and body emphasis, sexualization did not occur as often. This does not mean that there were not instances of objectification in the magazines, but rather that it is not the emphasis.

\section{De-Feminized Race}

The fourth and final research question sought to measure how de-feminization 
varied across race and ethnicity. In order to measure this question, it was first important to determine the distribution of images across race. Five racial categorizations were coded. This included Caucasian, African American, Hispanic/Latino, Asian and other. Results of this frequency distribution confirmed previous research isolated in chapter II that the images appear to be overly populated with white men. Table 10 shows that 95 of the 125 images were Caucasian, while only 30 were of another race. Each masculine and feminine feature was then measured across race using frequency tests as well as chisquared analysis.

\section{Table 10}

$\underline{\text { Race Distribution }}$

\begin{tabular}{lll}
\hline & Frequency & Percent \\
\hline Caucasian & 95 & $76.0 \%$ \\
African American & 15 & $12.0 \%$ \\
Asian & 3 & $2.4 \%$ \\
Hispanic/Latino & 5 & $4.0 \%$ \\
Other & 7 & $5.6 \%$ \\
\hline Total & 125 & $100.0 \%$ \\
\hline
\end{tabular}

After running the frequency test, calculations were made to determine how many more masculine and feminine images were depicted across each of the racial groups. In order to do this a chi-square test was run. No significant difference was found between groups across the fitness of clothing, touch, gaze, or body curvature. Upon running a chisquared analysis, build was the only one that had a significant difference. A chi-square analysis found significance between race and build: $\chi 2(16, \mathrm{~N}=125)=32.01, p<.05$. 
Cramér's phi was .51, which indicates that the race of the model accounted for $32 \%$ of the variability in regards to the build of the model (Table 11).

\section{Table 11}

Chi-Square Results along race

\begin{tabular}{lccc}
\hline \multicolumn{1}{c}{ Variable } & Chi-square & DF* & P \\
\hline Clothing Fit & 12.45 & 12 & .41 \\
Build & 32.01 & 16 & .01 \\
Touch & 22.60 & 16 & .13 \\
Gaze & 13.86 & 20 & .84 \\
Curvature & 17.68 & 16 & .34 \\
\hline
\end{tabular}

In addition a few interesting frequencies stood out that confirmed previous research about representation. For example, two of the three Asian models were coded as wearing tight clothing, engaged in feminine touch (self-touch), and high levels of curvature (curved and very curved). In this sample, Asian gay men were depicted as more feminized in their representation. In addition, the one model that was depicted in drag was African American. African American men were categorized at average to high depictions of masculinity when it came to how they were built, confirming previous research that showed how African American men are often depicted as hyper masculine. Even in the drag representation, the African American drag model was still depicted with higher levels of masculinity. These results do help to confirm that there is some degree of de-feminization that happens along boundaries of race, and reconfirms the way that media plays up long held stereotypes about particular identities. 


\section{CHAPTER V \\ DISCUSSION}

This research sought to understand how de-feminization occurs in mainstream gay male fashion magazines. The ultimate goal was to determine what gay men do and do not respond to by exploring the ways in which the stigmatization of femininity happens to occur. In an attempt to expand communication scholarship, and deconstruct traditional conceptions of femininity, several coding factors were used to determine what gets depicted for feminine gay men.

Michael Warner's theory (2010) of publics and counterpublic helped to frame the importance of this particular study. With representation and visibility in the media becoming more prominent, it is important to understand how gay men are responding to this consumer culture. Warner's theory helps to explain how both the public and counterpublic are bound up with masculinity and femininity. The public regulates meanings of gender and sexuality, while the counterpublic helps to articulate them. As Warner (2010) points out, gender and sexuality study is a public question of private life. Thus, Instinct magazine represented the intersection of these two spheres. Through this critical content analysis, we are further able to understand how gay male culture, as a counterpublic, articulates these private meanings of sexuality into the public sphere. 
Instinct magazine is representative of the conflict of the private life brought into that public sphere.

The second major theoretical framing that is articulated through this particular analysis is Judith Butler's (1993) work on gender performativity. This research expands traditional understandings of gender as being defined in relation to biological sex, and demonstrates how media images can show a performed gendered body. While gender is socially constructed, it is individually performed. This content analysis articulates how these gendered performances play out in relation to the images depicted. As such, this research attempted to explore how masculinity and femininity existed on a continuum. As demonstrated by the results, it is not possible to rule that one image is necessarily masculine or necessarily feminine. However, it is clear that masculinity and femininity plays out on a spectrum. That is, each image can have masculine and feminine performing instances. It is also clear that media caters their representation to one end of that spectrum. It is in understanding these performative instances that we are able to expand our understandings of how the particular social identity of the feminine performing gay man can be stigmatized and stereotyped.

The research does show that Instinct Magazine does depict masculine and feminine performing images. Based upon the frequency tests, chi-square analysis, and one-way ANOVA's we are able to determine that de-feminization does occur in Instinct Magazine. For example, when it came to measuring style and dress, only 35 wore tight fit clothing. Out of a sample size of 125 , that represents a significant number that are not emphasizing femininity. This confirms Cole's (2000) original claim that dress becomes a 
visible marker of performed gender. Tight fit clothing is often associated with femininity and as such, fewer of the ads reflected this particular performing trait.

Lanzieri \& Hildebrandt (2011) explained how increasing the size of the upper chest, and the emphasis on masculinity are becoming larger parts of standards of gay male attractiveness. As such, femininity (small framed individuals) is often stigmatized within their particular culture. According to both the one-way ANOVA, post hoc tests, and the frequency tests, the most feminine performing build was not as recurring. With only $14 \%$ of the sample size being identified as skinny, the research confirms that femininity is also underemphasized in regards to build. This is also one of the tests that found that there is a significant difference for how much clothing one had one and their build.

One significant finding was that touch did not demonstrate a significant defeminization. This could be due to modern consumer culture attempting to construct gay men through a homoerotic lens, as Clarke (2000) has pointed out. In other words, it is not uncommon for gay men to be depicted as touching another man, being touched by another man, or touching themselves in a sexual manner. The gay male is depicted through a homoerotic lens, where their hands are always sexually suggestive. Rohlinger (2002) argued that the display of erotic male gaze and touch are characteristics of an unknown sexuality. Thus, while the statistics do not represent clear masculine depictions, they also do not depict clear feminine images. This shows how displays of an unknown sexuality can de-emphasize the same performance. Another reason could be that this particular magazine only targets gay men. This means that oftentimes couples could be pictured and engaged in touch with one another, or some other form of touch. 
As a result, gay men are often pictured as engaged in some form of touch, making there be no significant de-feminization along the lines of touch.

However, de-feminization did occur along the lines of gaze and body position. Fewer models were engaged in a mental drift or gaze at another model, and only $5.6 \%$ were depicted as being slightly curved. Again these findings suggest that de-feminization does occur across each of these variables. Han (2000) has already explained why curvature of the body is directly related to femininity. Each of these particular categorizations help to explain the ways in which Instinct Magazine de-emphasizes femininity.

As Schroeder \& Zwick (2004) point out, interpreting advertising images allows us to understand the power they have and the ways they reflect the external world. Advertising images are important to the way in which we understand how gender is performed. This analysis does not merely explain the variations of gaze, touch, build, clothing, and position. Rather each of these reflects different levels of a spectrum of femininity. With every category, except touch, de-emphasizing femininity, it is clear that femininity can be performed in a particular image, and also stigmatized in that same image. Media negotiates sexuality (Kates, 1999) and current research has already indicated the desire for consumptive masculinity.

The findings from this particular research illustrate the way in which gay male fashion magazines are reflective of a larger socially held belief about femininity. This process is the in-group purification that is played out in the counterpublic sphere (Goffman, 1963), and is then articulated into a mainstream consumer culture that reiterates the significance it places on masculinity. Nardi's historical analysis, about 
questioning the role of effeminate men in regards to gay visibility, remains true within a modern context. As gay magazines begin to become mainstreamed, the de-feminization in this magazine reifies the normalization of masculinity. In addition, these findings reinforce the stigma and social sanctioning that justifies the construction of the "fag" (Schippers, 2007).

That construction comes back to the idea of the counterpublic. These representations literally take the ideas that play out in the counterpublic (the queer world making) and make them become mainstream understandings of sexuality. The nondisplaying of femininity reinforces the dangerous idea that "white, urban, heterosexual masculinity" (Clarkson, 2005, p. 252) should maintain being the norm. The danger of defeminization is that it commercializes an identity that is deemed as acceptable, and becomes reflective of new norms about gender performance. In the counterpublic, how one performs their gender can be the same cause for social shame.

This research expands the scope of representation and actively seeks to recognize the importance of how representation is constructed. Visibility is transformed in mass media, and commercialization has the ability to alter how one is viewed. As more marketing seeks to include gay populations as their consumer base, we must be cautious of what we depict, especially considering the racial trends of de-feminization are even more disturbing.

Of the 125 images coded, 95 of these images were white. While this sample size looked across five editions of this magazine, it seems to fall in line with traditional ideas that gay males are projected as white, upper-middle-class subjects (Um, 2012). McBride (2005) encourages us to understand the marketplace of design to understand what we 
accept and how we celebrate particular enactments of sexuality. Previous research has indicated that questions of masculinity and femininity are tied directly to race. While this research has confirmed significant difference in regards to build, a large problem of representation was reinforced. It is difficult to do a racial analysis, when there is not enough variation of racial diversity in the actual displayed images. Thus, gay visibility is attached to white representation. Despite this small sample size, Asian men were stereotypically depicted as curved and black men were stereotypically depicted as hypermasculine. Both of these demonstrate that despite the little representation, mainstream magazines are playing upon long held beliefs. These findings confirmed Delvon Johnson's (2013) experience about how rare it is for feminine black gay men to be seen in LGBT media.

De-feminization cannot happen across racial categories, merely because racial representation is little to non-existent. This reinforces the way racial and cultural scripts are constructed, and explain why LGBT people of color must also carve out their own space. This research was an attempt to expand the discussion about the intersections of race, femininity, and sexuality. In order to deconstruct the process of scripting that occurs, we must first begin by exploring long held beliefs. This racial component expands the idea of the public and the counterpublic even further to demonstrate that not only do gay male fashion magazines reflect the counterpublic; they also shape its beliefs.

As Bailey (2011) points out, Black LGBT members have a violent relationship to space. The violent relationship is expounded when looking at representation in mainstream gay male fashion magazines. As argued, counterpublics are complex, and vary across different performative dimensions. As such, there is a violent negotiation 
that appears to happen between the counterpublic and mainstream representation. LGBT people of color are essentially erased from the sphere of representation. As Jose Muñoz (1999) articulated, LGBT people of color learn how to disidentify with dominant structures in order to survive. LGBT people of color must live in the straight world, but they must also navigate through the complexity of the counterpublic where gay racism tends to manifest.

Marginalization, for LGBT people of color, happens in the counterpublic sphere and then gets articulated into the public sphere. Gay racism is inherently tied to questions of representation as well as masculinity and femininity. Marketers viewing gay men as upper to middle class white males suggests that the image that is articulated about gay visibility should be white. Bailey's work has explored the ways in which this spatial marginalization often happens because of race. LGBT people of color carve out their own spaces, because many queer spaces are white dominated and also white controlled.

Bailey (2011) also argues that Black LGBT members are often face "spatial marginalization" because they are denied from both the public and private spheres (i.e. the queer counterpublic) because of their race, sexual identity, and gender. The lack of representation found in gay male fashion magazines, like Instinct Magazine, are reflections of the racism often found in gay culture. LGBT people of color are forced to perform and carve out their own space (Johnson, 2005) in order to fight back against these oppressive structures that refuse to represent them.

What little representation that does exist in regards to race, still reinforces racial myths. Black gay men are constructed as hypersexual, and Asian gay men are constructed as overly feminine. As a result, racial representation is tied to the myths we 
have about how particular racialized bodies are supposed to perform their gender. Under the depictions found in these magazines, what is reinforced is that black gay men can never be feminine, and that Asian gay men can never be masculine. What is articulated in Instinct, as well as other magazines is not their own articulation of marginalization and stereotype, but is instead reflective of a queer world making project that is almost exclusively whitened in its definition, understanding, and articulation. As such, the counterpublic pervades the public sphere with these same dangerous racial ideologies.

\section{Implications}

Yep, Lovaas, and Elias (2008) have explained the way in which communication scholars are profoundly implicated in the maintenance of the hetero/homo binary, and that communication suffers from underexploring sexuality. As a discipline concerned with how we communicate and receive messages, the impacts that media has upon that the findings from this study are not only significant, but are necessary. In order to understand human interaction, it is important to not just understand what a message or images says, but what it means and signifies. This work sets a framework that moves away from static notions of representation and explores the intricacies of human interaction within particular subgroups. While plenty of research has explored media representation, and even how it effects our decisions and human interaction, much of this scholarship has not accounted for the unique variations among particular sub-groups. Yep argues that as scholars we must "disentangle and demystify the power of heteronormativity in our scholarship" and also embody "racialized knowledge of the human sexual subject" (Yep, 2003). This project challenges our understandings of 
human sexuality, pushes our understandings of masculinity and femininity beyond its relationship to biological sex, and offers a framework for exploring how these gendered performances operate within particular groups.

In addition this research speaks across and articulates the stigmatization of a particular population within the LGBT community. This research is an attempt to explore the conflicting identities that operate in a queer counterpublic in hopes to begin a dialogue about the ways in which masculinity gets normalized. Media is reflective of our behaviors, thoughts, and cultural interactions. As such, Instinct Magazine is not a counterpublic but is reflective of the ideologies held about feminine gay men in the queer counterpublics. This research challenges us to work to break down these beliefs about acceptable behavior, and actively disband the in-group purification process. Finally, it pushes marketers to be conscious of the images they display and the effects they can have on individuals.

\section{Limitations and Directions for Future Study}

There are a few limitations to this study. This research only analyzes images across the five summer editions of Instinct Magazine. While Instinct Magazine is a leading gay male fashion magazine, this research does not account for other gay male fashion magazines. While available research suggests that Instinct is a leading gay male fashion magazine, it does not run the spectrum of all available gay male magazines, or account for how representation could occur between mainstream gay and straight magazines. 
The second limitation of this study is its exploratory nature. This research attempts to analyze a phenomenon that is performative by nature, and quantify how this performative representation plays out with still mainstream images. As such, the full bodily motion that would typically be analyzed in theories of performance cannot be analyzed here because we cannot contextualize the body to the moment other than its display in a still image. As such, coding schemes had to be derived to measure performative instances. The focus on visual representation precludes analyzing moving variables such as hand gestures, and the way in which someone might walk. This thesis project attempts to quantify theories of performance to explain the way de-feminization occurs.

An additional limitation may have been in using Goffman's model of understanding the feminine. Goffman's writing was in the context of mainstream heterosexual magazines that often depicted men and women. As such, understandings of femininity can change in their meaning, when applied to gay men. As demonstrated with touch, it was difficult to determine what kind of tone the touch suggested. Goffman's model does not fully account for the complexity of gay male representation in these magazines. Goffman's model does not attempt to understand the variations in gaze and touch, along the lines of sexual dominance and male on male interactions. A new scale for measuring variables, such as touch and gaze, needs to account for the tone of these performances, to further expand an understanding of gay male life. In addition, the measuring of build did not necessarily account for overweight or unfit in this study. This is primarily because these representations were not depicted. The build scale attempted to measure levels of muscularity and fitness but did not measure how overweight or unfit 
models fit in. However, overweight or unfit models did not appear in the media representation and as such, it did not effect the measuring of build here. However, it could effect future studies and so the scale should be expanded to account for these various dimensions along the lines of masculinity and femininity.

Despite these limitations, this exploratory content analysis sets the framework for further investigation. While there is little representation of femininity in these magazines, it is important to note that there is some. Many research projects have explored femininity in relation to women, or explained it as a stigmatized identity. Virtually no study, has explored the process of de-feminization that occurs in gay male culture. There is further need to expand this research to examine the impacts that these representations could have on those who identify as feminine performing gay men. Particularly, previous research has isolated the way in which men are beginning to respond to consumer culture, and evaluate themselves in relation to images they see in the mainstream. Future research should explore the ways in which stigmatization and stereotypes, as well as body image issues play out for those negatively affected by these representations.

Finally, this research looked at how often masculine and feminine representations appeared over various dimensions of the body. Future research can take the scales that are presented here and explore how other dimensions effect the image. For example, a study could look at how having more than one person in the image changed the tone of the image. Others could look at how the tone of the touch and face alter the meanings of masculinity and femininity, as well as the image itself. Because sexual dominance was not a theme that was coded, a final study could look at the sexual themes in the images. 
Sexual, not sexual, and hypersexuality seem to be important in many of the images presented. Additional studies should look at these sexual themes, and explore how they also contribute to a larger understanding of masculinity and femininity. 


\section{REFERENCES}

Angelini, J. \& Bradley, S. (2010). Homosexual imagery in print advertisements:

Attended, remembered, and disliked. Journal of Homosexuality, 57, 485-502

Alvarez, E. (2008). Muscle boys: Gay gym culture. New York, NY: Haworth Press

Avila-Saavedra (2009). Nothing queer about queer television: Televised construction of gay masculinities. Media Culture Society, 31, 5-21. doi:

$10.1177 / 0163443708098243$

Bailey, M. (2011). Gender/Racial realness: Theorizing the gender system in ballroom culture. Feminist studies, 37, 365-386.

Bailey, M. (2013). Butch Queens up in pumps: Gender, performance, and ballroom culture in Detroit. Ann Arbor, MI: University of Michigan Press.

Butler, J. (1993). Critically queer. GLQ: A Journal of Lesbian and Gay Studies, 1(1), 1732. doi: $10.1215 / 10642684-1-1-17$

Butler, J. (1999). Gender trouble. New York, NY: Routledge Press

Cision (2012). Top Lists. Retrieved from

http://www.cision.com/us/2012/06/top-10-gay-and-lesbian-magazines/

Clarke, E. (2000). Virtuous vice: homoeroticism and the public sphere. Durham \& London: Duke University Press.

Clarkson, J. (2005). Masculinity’s makeover: Queer Eye, consumer masculinity, and 
"straight-acting" gays. Journal of Communication Inquiry, 29, 235-255. doi:

$10.1177 / 0196859905275234$

Cole, S. (2000). 'Don we now our gay apparel: Gay men's dress in the twentieth century. Oxford, UK: Oxford International Publishers.

Drummond, M. (2005). Asian gay men's bodies. Journal of Men's Studies, 13(3), 2300. doi: 10.3149/jms.1303.291

Eguchi, S. (2011). Negotiating sissyphobia: A critical/interpretive analysis of one "femme" gay Asian Body in the heteronormative world. Journal of Men's Studies, 19(1), 37-56. doi: 10.3149/jms.1901.37

Fee, D. (2000). “One of the guys": Instrumentality and intimacy in gay men's friendships with straight men. In. P. Nardi (Ed.), Gay masculinities (pp. 44-65). Thousand Oaks, CA: Sage Publications.

Glick, P., Gangl, C., Gibb, S., Klumpner, S., \& Weinberg, E. (2007). Defensive reactions to masculinity threat: More negative affect toward effeminate (but not masculine) gay men. Sex Roles, 57, 55-59. doi: 10.1007/s11199-007-9195-3.

Goffman, E. (1963). Stigma: Notes on the management of spoiled identity (reprint) New York: Touchstone.

Goffman, E. (1979). Gender Advertisements. New York: Harper \& Row, Publishers.

Halkitis, P. N. (2000). Masculinity in the age of AIDS: HIV-Seropositive gay men and the "buff agenda". In. P. Nardi (Ed.), Gay masculinities (pp. 130-151). Thousand Oaks, CA: Sage Publications.

Han, S. (2000). Asian American gay men's (dis)claim on masculinity. In. P. Nardi (Ed.), Gay masculinities (pp. 206-223). Thousand Oaks, CA: Sage Publications. 
Hines, C. (Producer \& Director). (2010). The Adonis Factor [DVD]. United States: LOGO TV.

Instinct (No Date). Advertising. Retrieved from http://instinctmagazine.com/magazine/advertising

Jacob, J. \& Cerny, C. (2004). Radical drag appearances and identity: The embodiment of male femininity and social critique. Clothing and Textile Research Journal, 22(3), 122-134. doi: 10.1177/0887302X04022200303

Jankowski, G. S., Fawkner, H., Slater, A., Tiggemann, M. (2014). “Appearance potent”? A content analysis of UK gay and straight men's magazines. Body Image 11. 474-481. http://dx.doi.org/10.1016/j.bodyim.201407.010

Johnson, D. (2013, March 20). The shade on feminine black gay men. Retrieved October 14, 2014, from http://gbmnews.com/wp/archives/6908

Johnson, E. (2005). "Quare" studies, or (almost) everything I know about queer studies I learned from my grandmother. In E. Johnson \& M. Henderson (Eds.), Black queer studies: A critical anthology (pp. 124-157). Durham, NC: Duke University Press.

Kates, S. (1999). Making the ad perfectly queer: Marketing "normality" to the gay men's community. Journal of Advertising, XXVIII(1), 25-37. doi:

$10.1080 / 00913367.1999 .10673574$

Kousari-Rad, P., \& McLaren, S. (2013). The relationships between sense of belonging to the gay community, body image dissatisfaction, and self-esteem among Australian gay men. Journal Of Homosexuality, 60(6), 927-943. doi:10.1080/00918369.2013.774866 
Lanzieri, N. \& Hildebrandt, T. (2011). Using hegemonic masculinity to explain gay male attraction to muscular and athletic men. Journal of Homosexuality 58(2), 275293. doi: $10.1080 / 00918368.2011 .540184$

Leavy, P., Gnong, A., \& Ross, L. S. (2009). Femininity, masculinity, and body image issues among college-age women: An in-depth and written interview study of the mind-body dichotomy. The Qualitative Report 14(2), 261-292. http://www.nova.edu/ssss/QR/QR14-2/leavy.pdf

McBride, D. (2005). Why I hate Abercrombie Fitch: Essays on race and sexuality. New York, NY: New York University Press

Messias, L. (2011). Toward a new sissiography: The sissy in body, abuse, and space in performance practice (Doctoral dissertation), Retrieved from The Central School of Speech and Drama, University of London

Munoz, J. (1999). Disidentifications: Queers of color and the performance of politics. Minneapolis, MN: University of Minnesota Press.

Mutchler, M. G. (2000). Seeking sexual lives: Gay youth and masculinity tensions. In. P. Nardi (Ed.), Gay masculinities (pp. 12-43). Thousand Oaks, CA: Sage Publications.

Nardi, P. (2000). “Anything for a sis, Mary": An introduction to gay masculinities. In. P. Nardi (Ed.), Gay masculinities (pp. 1-11). Thousand Oaks, CA: Sage Publications.

Oakenfull, G., \& Greenlee, T. (2005). Queer eye for a gay guy: Using market-specific symbols in advertising to attract gay consumers without alienating the mainstream. Pyschology \& Marketing, 22(5), 421-439. doi: 10.1002/mar.20066 
Paechter, C. (2006). Masculine femininities/feminine masculinities: Power, identities, and gender. Gender and Education. 18(3), 253-263. doi: $10.1080 / 09540250600667785$

Pope, H., Phillps, K., \& Olivardia, R. (2000). The Adonis Complex: The secret crisis of male body obsession. New York, NY: The Free Press

Reichert, T., \& Carpenter, C. (2004). An update on sex in magazine advertising: 1983 to 2003. Journalism and Mass Communication Quarterly 81(4), 823-837.

Rohlinger, D. A. (2002). Eroticizing men: Cultural influences on advertising and male objectification. Sex Roles, 46(3/4), 61-74. doi: 0360-0025/02/0200-0061/0

Sanchez, F., Greenberg, S., Liu W., \& Vilain, E. (2009). Reported effects of masculine ideals on gay men. Pyschol Men Masc, 10(1), 73-87. doi: 10.1037/a0013513.

Sánchez, F. \& Vilain, E. (2012). "Straight-Acting Gays": The relationship between masculine consciousness, anti-effeminacy, and negative gay identity. Archive Sexual Behavior. 41, 111-119. doi: 10.1007/s10508-012-9912-z

Sandford, T. (2005). Sexual orientation and gender: Stereotypes and beyond. Archives of Sexual Behavior, 34(6), 595-611. doi: 0004-0002/05/1200-0595/0.

Saucier, J. \& Caron, S. (2008). An investigation of content and media images in gay men's magazines. Journal of Homosexuality, 55(3), 504-523. doi: $10.1080 / 00918360802345297$

Sender, K. (1999). Selling sexual subjectivities: Audiences respond to gay window advertising. Critical Studies in Mass Communication, 16, 172-196. doi: 4902338838

Schippers, M. (2007). Recovering the feminine other: masculinity, femininity, and 
gender hegemony. Theory and Society, 36, 85-102. doi: 10.1007/s1186-007$9022-4$

Schroeder, J. \& Zwick, D. (2004). Mirrors of masculinity: Representation and identity in advertising images. Consumption, Markets, and Culture, 7, 21-52. doi: $10.1080 / 1025386042000212383$

Stets, J. E., \& Burke, P. J. (2000). Femininity/Masculinity. Encyclopedia of Sociology. (Revised ed) New York: MacMillan.

Taywaditep, K. (2008). Marginalization among the marginalized. Journal of Homosexuality, 42(1). 1-28. doi: 10.1300/J082v42n01_01

Tsai, W. (2010). Assimilating the queers: Representations of lesbians, gay men, bisexual, and transgender people in mainstream advertising. Advertising \& Society Review, 11(1). doi: 10.1353/asr.0.0042

Tsai, W. (2013). How minority consumers use targeted advertising as pathways to selfempowerment. Journal of Advertising, 40(3), 85-98. doi: 10.2753/JOA00913367400307

Um, N. (2012). Seeking the holy grail through gay and lesbian consumers: An exploratory content analysis of ads with gay/lesbian-specific content. Journal of Marketing Communications, 18, 133-149. doi:10.1080/13527266.2010.489696

Warner, M. (1999). The trouble with normal: Sex, politics, and the ethics of queer life. Cambridge, MA: Harvard University Press.

Warner, M. (2010). Publics and counterpublics. (First paperback ed., third printing). Brooklyn, NY: Zone Books

Yep, G. (2003). The violence of heteronormativity in communication studies. Journal of 
Homosexuality, 45(2-4), 11-59. doi: 10.1300/J082v45n02_02

Yep, G.A., Lovaas, K.E., Elia, J. P. (2008) Introduction. Journal of Homosexuality, 45(24), 1-10, doi: 10.1300/J082v45n02_01 


\section{APPENDIX A \\ CODEBOOK}

\begin{tabular}{|c|c|c|c|c|}
\hline $\begin{array}{l}\text { Variable } \\
\text { Name }\end{array}$ & $\begin{array}{l}\text { Varia } \\
\text { ble } \\
\text { Label }\end{array}$ & $\begin{array}{l}\text { Valid } \\
\text { Value } \\
\text { s }\end{array}$ & Definitions & Notes \\
\hline Image ID & & $1-200$ & $\begin{array}{l}\text { Each image is } \\
\text { given a number }\end{array}$ & \\
\hline $\begin{array}{l}\text { 1. } \\
\text { Background } \\
\text { Details }\end{array}$ & \multicolumn{4}{|c|}{$\begin{array}{l}\text { These are basic background questions about each of the images } \\
\text { that are being analyzed }\end{array}$} \\
\hline \multirow[t]{4}{*}{ A) Age } & Age & $\begin{array}{l}1,2 \\
3,4\end{array}$ & $\begin{array}{l}1=\text { Youth } \\
(<18)\end{array}$ & \\
\hline & & & $\begin{array}{l}2=\text { Young } \\
\text { Adult (19-35) }\end{array}$ & \\
\hline & & & $\begin{array}{l}\text { 3=Middle Age } \\
(36-50)\end{array}$ & \\
\hline & & & $\begin{array}{l}\text { 4= Older Adult } \\
(51+)\end{array}$ & \\
\hline \multirow[t]{5}{*}{ B) Race } & Race & $\begin{array}{l}1,2 \\
3,4,5\end{array}$ & $1=$ Caucasian & \\
\hline & & & $\begin{array}{l}2=\text { African } \\
\text { American }\end{array}$ & \\
\hline & & & $3=$ Asian & \\
\hline & & & 4= Hispanic & \\
\hline & & & $5=$ Other & \\
\hline $\begin{array}{l}\text { 2) Image } \\
\text { Details }\end{array}$ & \multicolumn{4}{|c|}{$\begin{array}{c}\text { These questions ask about the details of the image, including its } \\
\text { purpose, how many are in the image, and what is depicted }\end{array}$} \\
\hline \multirow[t]{2}{*}{ A) Туре } & Type & 1,2 & $\begin{array}{l}1= \\
\text { Advertisement }\end{array}$ & \\
\hline & & & $\begin{array}{l}2=\text { Magazine } \\
\text { Content }\end{array}$ & \\
\hline \multirow[t]{2}{*}{$\begin{array}{l}\text { B) \# of } \\
\text { People in } \\
\text { Image }\end{array}$} & $\begin{array}{l}\text { NOPP } \\
\text { LIMG }\end{array}$ & $\begin{array}{l}0 \\
1,2,3 \\
4,5\end{array}$ & $0=$ No person & \\
\hline & & & $\begin{array}{l}1=1 \text { Person in } \\
\text { Image }\end{array}$ & \\
\hline
\end{tabular}




\begin{tabular}{|c|c|c|c|c|}
\hline & & & $\begin{array}{l}2=2 \text { People in } \\
\text { Image }\end{array}$ & \\
\hline & & & $\begin{array}{l}3=3 \text { People in } \\
\text { Image }\end{array}$ & \\
\hline & & & $\begin{array}{l}4=4 \text { People in } \\
\text { Image }\end{array}$ & \\
\hline & & & $\begin{array}{l}5=5 \text { or More } \\
\text { People in } \\
\text { Image }\end{array}$ & \\
\hline $\begin{array}{l}\text { C) Visual } \\
\text { Depiction }\end{array}$ & $\begin{array}{l}\text { Image } \\
\text { Type }\end{array}$ & $\begin{array}{l}1,2 \\
3,4 \\
5,6\end{array}$ & 1= Face Image & \\
\hline & & & $\begin{array}{l}2=\text { Eye Only } \\
\text { Image }\end{array}$ & \\
\hline & & & $\begin{array}{l}3=\text { Lips Only } \\
\text { Image }\end{array}$ & \\
\hline & & & $\begin{array}{l}4=\text { Upper } \\
\text { Torso Image }\end{array}$ & Above the waistline \\
\hline & & & $\begin{array}{l}5=\text { Lower } \\
\text { Torso }\end{array}$ & Waistline and below \\
\hline & & & $\begin{array}{l}6=\text { Full Body } \\
\text { Shot }\end{array}$ & \\
\hline $\begin{array}{l}\text { Masculinity/ } \\
\text { Femininity }\end{array}$ & \multicolumn{4}{|c|}{ These factors measure masculinity and femininity. } \\
\hline & \multicolumn{4}{|c|}{$\begin{array}{l}\text { Lower numbers indicate masculinity and higher numbers } \\
\text { indicate femininity, except when amounts are measured }\end{array}$} \\
\hline \multicolumn{5}{|l|}{ 3. Style/Dress } \\
\hline \multirow[t]{4}{*}{$\begin{array}{l}\text { A) Clothing } \\
\text { Fit }\end{array}$} & FIT & $1,2,3$ & $\begin{array}{l}\text { 0. No clothes } \\
\text { depicted }\end{array}$ & \\
\hline & & & $\begin{array}{l}\text { 1. Loose } \\
\text { Fitting }\end{array}$ & $\begin{array}{l}\text { Clothes hang loosely on the } \\
\text { model }\end{array}$ \\
\hline & & & 2. Fit & Clothes fit just perfect \\
\hline & & & 3. Tight Fit & $\begin{array}{l}\text { Clothes are tightly fitted } \\
\text { around their body }\end{array}$ \\
\hline \multicolumn{5}{|l|}{$\begin{array}{l}\text { B) Clothing } \\
\text { Type }\end{array}$} \\
\hline $\begin{array}{l}\text { (1) male } \\
\text { clothing }\end{array}$ & $\begin{array}{l}\text { MaleT } \\
\text { ype }\end{array}$ & $\begin{array}{l}0 \\
1,2,3\end{array}$ & $0=$ None & \multirow{2}{*}{$\begin{array}{l}\text { This indicates how many } \\
\text { items of male clothing are } \\
\text { being worn. Male }\end{array}$} \\
\hline & & & $1=1-2$ items & \\
\hline
\end{tabular}




\begin{tabular}{|c|c|c|c|c|}
\hline & & & & $\begin{array}{c}\text { clothing }=\text { men's underwear, } \\
\text { jeans, t-shirts, button } \\
\text { downs, etc }\end{array}$ \\
\hline & & & $2=3-4$ items & \\
\hline & & & $3=5+$ items & \\
\hline$\frac{\text { (2) female }}{\text { clothing }}$ & Ftype & $\begin{array}{l}0,1,2 \\
3\end{array}$ & $0=$ None & \multirow{2}{*}{$\begin{array}{l}\text { This indicates how many } \\
\text { items of female clothing are } \\
\text { being worn. Female } \\
\text { clothing=Makeup, Heels, } \\
\text { Dress/Skirts, Female } \\
\text { Jewelry, etc. }\end{array}$} \\
\hline & & & $1=1-2$ items & \\
\hline & & & $2=3-4$ items & \\
\hline & & & $3=5+$ items & \\
\hline & & & & \\
\hline \multirow[t]{2}{*}{$\begin{array}{l}\text { (3) drag } \\
\text { appearance }\end{array}$} & drag & 1,2 & $1=\mathrm{No}$ & $\begin{array}{l}\text { Do the models appear } \\
\text { dressed in drag } \\
\text { performance? }\end{array}$ \\
\hline & & & $2=\mathrm{Yes}$ & \\
\hline \multirow[t]{5}{*}{ 4. Build } & Build & $1,2,3$ & $1=$ Muscular & $\begin{array}{l}\text { This model is not just fit, } \\
\text { but appears to be the } \\
\text { "bodybuilding type" and is } \\
\text { muscular. }\end{array}$ \\
\hline & & & 2=Athletic/Fit & $\begin{array}{l}\text { The model is built and well } \\
\text { toned. }\end{array}$ \\
\hline & & & $3=$ Average & $\begin{array}{l}\text { The model is not thin, but } \\
\text { not muscular. They appear } \\
\text { to have a normal body size }\end{array}$ \\
\hline & & & $4=$ Lean/Fit & $\begin{array}{l}\text { The model is very thin, but } \\
\text { their body is also toned and } \\
\text { appears to have some } \\
\text { muscle }\end{array}$ \\
\hline & & & 5=Skinny & $\begin{array}{l}\text { The model is very } \\
\text { small/thing and has no } \\
\text { muscular build }\end{array}$ \\
\hline \multirow[t]{2}{*}{ 5. Touch } & Touch & $\begin{array}{l}0,1 \\
2,3,4 \\
\end{array}$ & $\begin{array}{l}0=\text { No touch at } \\
\text { all }\end{array}$ & $\begin{array}{l}\text { (Model is not touching } \\
\text { anyone or anything) }\end{array}$ \\
\hline & & & $1=$ Touching & (Model is touching an \\
\hline
\end{tabular}




\begin{tabular}{|c|c|c|c|c|}
\hline & & & an Object & object) \\
\hline & & & $\begin{array}{l}2=\text { Unknown } \\
\text { Touch }\end{array}$ & $\begin{array}{l}\text { (Model touch is } \\
\text { indeterminate, or is } \\
\text { engaged in multiple } \\
\text { touches) }\end{array}$ \\
\hline & & & $\begin{array}{l}3=\text { Touch with } \\
\text { another }\end{array}$ & $\begin{array}{l}\text { (Model is touching or } \\
\text { holding to another man) }\end{array}$ \\
\hline & & & 4=Self-Touch & $\begin{array}{l}\text { (Model is touching their } \\
\text { body in some way) }\end{array}$ \\
\hline \multirow[t]{6}{*}{ 6. Gaze } & Gaze & $\begin{array}{l}0,1,2, \\
3,4,5\end{array}$ & $0=$ No Gaze & Gaze is non-existent \\
\hline & & & $\begin{array}{l}1=\text { Gaze at } \\
\text { Audience }\end{array}$ & $\begin{array}{l}\text { Model is gazing at someone } \\
\text { not pictured }\end{array}$ \\
\hline & & & $\begin{array}{l}2=\text { Unknown } \\
\text { type of gaze }\end{array}$ & Gaze is indeterminate \\
\hline & & & $3=$ Self-Gaze & $\begin{array}{l}\text { Gaze is directed towards } \\
\text { the self }\end{array}$ \\
\hline & & & $\begin{array}{l}=\text { Gaze at } \\
\text { another model }\end{array}$ & $\begin{array}{l}\text { Model is looking at another } \\
\text { person }\end{array}$ \\
\hline & & & $5=$ Mental Drift & $\begin{array}{l}\text { Model is looking into the } \\
\text { distance (slightly altered) }\end{array}$ \\
\hline \multicolumn{5}{|l|}{ 7. Position } \\
\hline \multirow[t]{3}{*}{ a) Location } & $\begin{array}{l}\text { LOCA } \\
\text { TE }\end{array}$ & $0,1,2$ & $\begin{array}{l}0=\text { Not } \\
\text { Pictured with } \\
\text { anyone }\end{array}$ & Not pictured \\
\hline & & & $\begin{array}{l}1=\text { Frontal } \\
\text { Location }\end{array}$ & $\begin{array}{l}\text { Model/Person is located in } \\
\text { the front of the image }\end{array}$ \\
\hline & & & $\begin{array}{l}2=\text { Located } \\
\text { behind } \\
\text { someone }\end{array}$ & $\begin{array}{l}\text { Model is located directly } \\
\text { behind someone }\end{array}$ \\
\hline \multirow[t]{4}{*}{$\begin{array}{l}\text { b) Body } \\
\text { Curvature }\end{array}$} & $\begin{array}{l}\text { BodyC } \\
\text { URVE }\end{array}$ & $\begin{array}{l}0,1,2, \\
3,4\end{array}$ & $0=$ Not Pictured & \\
\hline & & & $\begin{array}{l}1=\text { No curve at } \\
\text { all }\end{array}$ & $\begin{array}{l}\text { Standing/sitting/laying } \\
\text { straight up }\end{array}$ \\
\hline & & & $\begin{array}{l}2=\text { Slightly } \\
\text { Curved }\end{array}$ & $\begin{array}{l}\text { Body has a small curve/ } \\
\text { slightly noticeable }\end{array}$ \\
\hline & & & 3- Curved & Body has a noticeable \\
\hline
\end{tabular}




\begin{tabular}{|c|c|c|c|c|}
\hline & & & & curve, but normal \\
\hline & & & $\begin{array}{l}4=\text { Very } \\
\text { Curved }\end{array}$ & $\begin{array}{l}\text { Body is heavily curved or } \\
\text { appears to bend noticeably }\end{array}$ \\
\hline $\begin{array}{l}8 . \\
\text { Objectificati } \\
\text { on }\end{array}$ & $\begin{array}{l}\text { These } \\
\text { questi } \\
\text { ons } \\
\text { measu } \\
\text { re how } \\
\text { much } \\
\text { objecti } \\
\text { ficatio } \\
\text { n } \\
\text { appear } \\
\text { s. } \\
\text { Lower } \\
\text { \#'s= } \\
\text { less, } \\
\text { and } \\
\text { higher } \\
\text { \#'s= } \\
\text { more } \\
\text { objecti } \\
\text { ficatio } \\
\text { n }\end{array}$ & & & \\
\hline \multirow[t]{4}{*}{ A. Clothing } & $\begin{array}{l}\text { Clothi } \\
\text { ng }\end{array}$ & $\begin{array}{l}1,2,3 \\
4\end{array}$ & $\begin{array}{l}1=\text { Fully } \\
\text { Clothed }\end{array}$ & $\begin{array}{l}\text { All parts of body are } \\
\text { covered }\end{array}$ \\
\hline & & & $\begin{array}{l}2=\text { Partially } \\
\text { Clothed }\end{array}$ & Half of the body is covered \\
\hline & & & $\begin{array}{l}3=\text { Barely } \\
\text { Clothed }\end{array}$ & $\begin{array}{l}\text { Less than half of the body } \\
\text { is covered. They may each } \\
\text { only have one }\end{array}$ \\
\hline & & & $4=$ Not Clothed & $\begin{array}{l}\text { The model appears to have } \\
\text { no clothes on }\end{array}$ \\
\hline \multirow[t]{2}{*}{$\begin{array}{l}\text { B. Display } \\
\text { with sexual } \\
\text { object }\end{array}$} & $\begin{array}{l}\text { SEXO } \\
\text { BJ }\end{array}$ & 1,2 & $1=\mathrm{No}$ & $\begin{array}{l}\text { The models appear to be } \\
\text { displayed with an object in } \\
\text { a way that could appear } \\
\text { sexual (Penile shaped, } \\
\text { sexual shaped objects) }\end{array}$ \\
\hline & & & $2=Y e s$ & \\
\hline
\end{tabular}




\begin{tabular}{|l|l|l|l|l|}
\hline $\begin{array}{l}\text { C. Display } \\
\text { with sexual } \\
\text { text }\end{array}$ & $\begin{array}{l}\text { SEXT } \\
\text { XT }\end{array}$ & 1,2, & $1=$ No & \multirow{2}{*}{$\begin{array}{c}\text { The text of the image the } \\
\text { model appears in is } \\
\text { sexually explicit or } \\
\text { sexually suggestive }\end{array}$} \\
\hline & & & $2=$ Yes & \\
\hline $\begin{array}{l}\text { D. Emphasis } \\
\text { on Male Sex }\end{array}$ & $\begin{array}{l}\text { MALE } \\
\text { SEX }\end{array}$ & 1,2 & $1=$ No & $\begin{array}{c}\text { The model emphasis his } \\
\text { body as sexual (holding of } \\
\text { the crotch, noticeable } \\
\text { bulge, short underwear, or } \\
\text { any other noticeable } \\
\text { sexualization of the body) }\end{array}$ \\
\hline & & $2=$ Yes & \\
\hline
\end{tabular}


APPENDIX B:

CODING ANSWER SHEET

CODER ID:

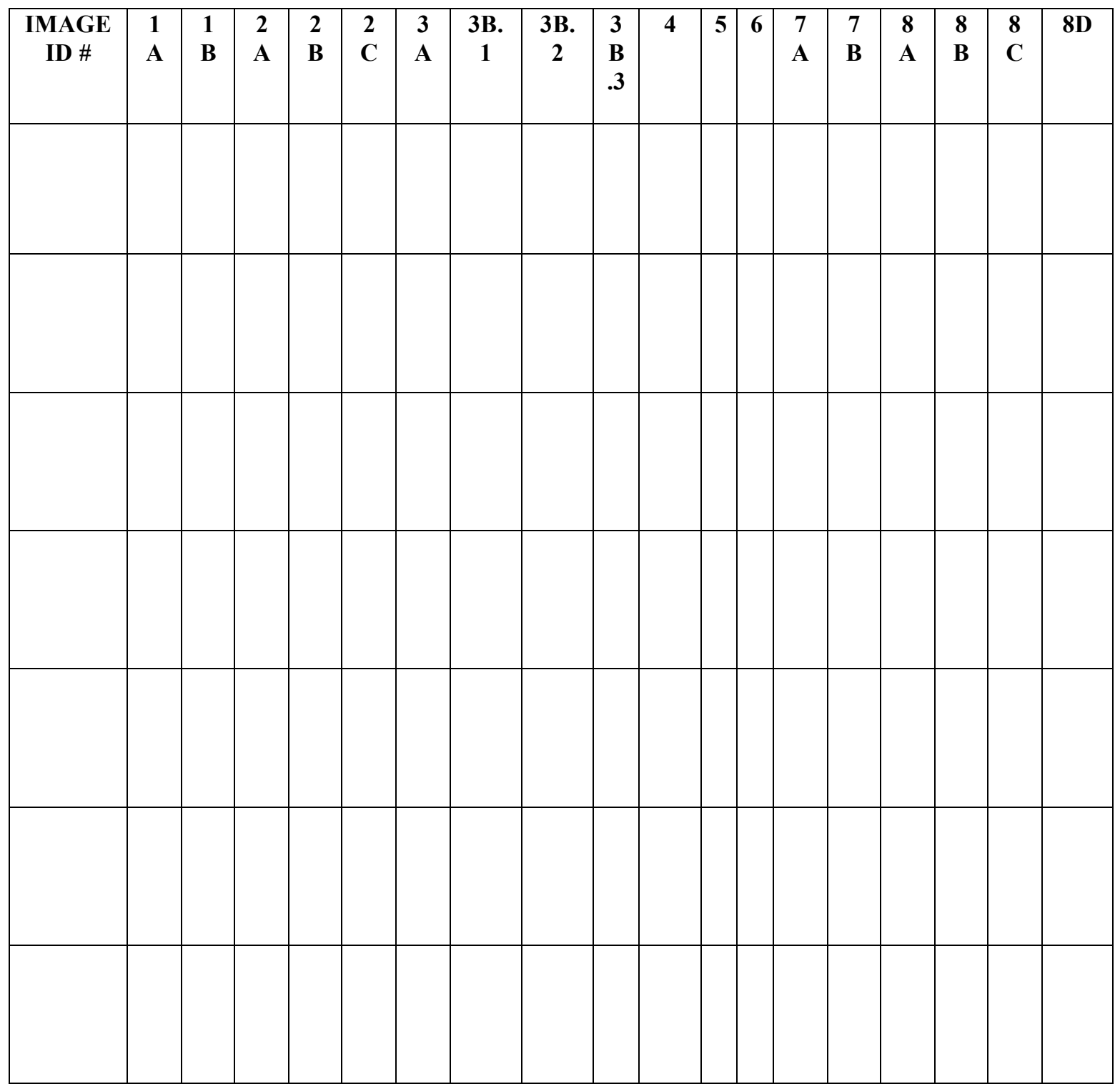


APPENDIX C

SUMMARIZED FREQUENCY FINDINGS

\section{Table 12}

Summary of Findings

\begin{tabular}{|c|c|c|}
\hline Item Measured & Item Scale & Frequency \\
\hline \multicolumn{3}{|l|}{ Background Details } \\
\hline \multirow[t]{4}{*}{ Age } & Youth $(<18)$ & 2 \\
\hline & $\begin{array}{l}\text { Young Adult (19- } \\
35 \text { ) }\end{array}$ & 89 \\
\hline & Middle Age (36-40) & 34 \\
\hline & Older Adult $(51+)$ & 0 \\
\hline \multirow[t]{5}{*}{ Race } & Caucasian & 95 \\
\hline & African American & 15 \\
\hline & Asian & 3 \\
\hline & Hispanic/Latino & 5 \\
\hline & Other & 7 \\
\hline \multicolumn{3}{|l|}{ Image Details } \\
\hline \multirow[t]{2}{*}{ Image Type } & Advertisement & 76 \\
\hline & Magazine Content & 49 \\
\hline \multirow[t]{6}{*}{ \# of People In Image } & No Person & 1 \\
\hline & 1 Person in image & 42 \\
\hline & 2 People in image & 51 \\
\hline & 3 People in image & 5 \\
\hline & 4 People in image & 13 \\
\hline & $\begin{array}{l}5 \text { or more People in } \\
\text { image }\end{array}$ & 13 \\
\hline \multirow[t]{6}{*}{ Visual Depiction } & Face Image & 7 \\
\hline & Eye only & 0 \\
\hline & Lips Only & 0 \\
\hline & Upper Torso & 74 \\
\hline & Lower Torso & 0 \\
\hline & Full Body & 44 \\
\hline
\end{tabular}


Masculinity/Femininity

\section{Style/Dress}

Clothing Fit

No clothes 20

Loose fitting 5

Fit 65

Tight Fit $\quad 35$

Clothing Type

Male Clothing

$\begin{array}{ll}\text { None } & 21 \\ 1-2 \text { items } & 76 \\ 3-4 \text { items } & 23 \\ \text { 5+ items } & 5\end{array}$

Female Clothing

None

115

1-2 items 9

3-4 items 1

$5+$ items 0

Drag Appearance

No

124

Yes

1

Build

Muscular 4

Athletic/Fit $\quad 34$

Average 34

Lean/Fit $\quad 35$

Skinny 18

Touch No touch at all $\quad 30$

Touching an object 28

Unknown touch $\quad 14$

Touch with another 32

Self-Touch 21

Gaze No gaze 4

Gaze at audience $\quad 64$

Unknown type of $\quad 14$

gaze

Self-gaze 3

Gaze at another

model

Mental drift 


\begin{tabular}{|c|c|c|}
\hline \multicolumn{3}{|l|}{ Position } \\
\hline \multirow[t]{3}{*}{ Location } & $\begin{array}{l}\text { Not pictured with } \\
\text { anyone }\end{array}$ & 43 \\
\hline & Frontal location & 65 \\
\hline & $\begin{array}{l}\text { Located behind } \\
\text { someone }\end{array}$ & 17 \\
\hline \multirow[t]{5}{*}{ Body Curvature } & Not pictured & 10 \\
\hline & No curve at all & 31 \\
\hline & Slightly curved & 57 \\
\hline & Curved & 20 \\
\hline & Very curved & 7 \\
\hline \multicolumn{3}{|l|}{ Objectification } \\
\hline \multirow[t]{4}{*}{ Clothing } & Fully clothed & 73 \\
\hline & Partially clothed & 17 \\
\hline & Barely clothed & 17 \\
\hline & Not clothed & 18 \\
\hline \multirow[t]{2}{*}{$\begin{array}{l}\text { Display with sexual } \\
\text { object }\end{array}$} & No & 112 \\
\hline & Yes & 13 \\
\hline \multirow[t]{2}{*}{ Display with sexual text } & No & 111 \\
\hline & Yes & 14 \\
\hline \multirow[t]{2}{*}{ Emphasis on Male Sex } & No & 97 \\
\hline & Yes & 28 \\
\hline
\end{tabular}




\section{CURRICULUM VITA}

Christopher J. Vincent

1235 South Brook Street Apt 2

Louisville, KY 40203

(502)299-2120

cjvinc01@louisville.edu

\section{Education}

B.A. in English, Department of English, University of Louisville Minor: Sociology

\section{Career History/Relevant Employment}

- Assistant Debate Coach, University of Louisville, August 2013-present

- Director of Speech \& Debate, J. Graham Brown School, August 2013-present

- Director of Speech \& Debate, Fern Creek Traditional High School, August 2011June 2013

- Advisory Board Member/Secretary, Wilson Wyatt Debate League, March 2013December 2014

- Advisory Board Member/Vice President, Wilson Wyatt Debate League, December 2014-Present

\section{Teaching Experience}

University of Louisville, Debate Program

Graduate Assistant Fall 2013-Present

University of North Texas Mean Green Workshop Summer Debate Institute Summer 2014

Indiana University Summer Debate Institute

Curriculum Director, Lincoln Douglas Debate: Summer 2012, 2013, 2014 
Memphis Urban Debate League Summer Debate Institute

Summer 2011, 2012, 2013, 2014

Kentucky National Debate Institute, University of Kentucky

Summer 2010

\section{Research/Publications}

Vincent, C. (2014). Next level debating: From the local to the national spotlight. Conference presentation at KYSPEAK, University of Kentucky, Lexington, KY.

Vincent, C. (2013). Reconceptualizing our performances: Accountability in Lincoln Douglas Debate. Victory Briefs. http://victorybriefs.com/vbd/2013/10/reconceptualizing-our-performances-accountability-in-lincoln-douglas-debate

\section{Awards and Honors Received}

- ACC Debate Team Coach, University of Louisville, April 2015

- Graduate Assistantship, University of Louisville, August 2013-present

- Cross-Examination Debate Association National Championship - Final Round Panelist, March 2014

- Corey Knox Debate Scholarship, University of Louisville, August 2008-May 2013

- Double-Octafinals National Debate Tournament, April 2013

- Double Octafinals Cross-Examination Debate Association National Tournament, March 2013

- Wilson Wyatt Debate League Director's Service Award, May 2013

- Coach of Kentucky State Debate Champion- 2011, 2013

- Tournament of Champions- Final Round Panelist, May 2013

\section{Professional Memberships/Affiliations}

- Member, Cross-Examination Debate Association

- Member, National Debate Tournament

- Member, National Speech \& Debate Association

- Member, National Debate Coaches Association

- Member, Kentucky High School Speech League

\section{Service}

- Provide instruction and coaching to individual students nationally 